\title{
Alaska's Mineral Industry
}

\section{6: A SUMMARY}

Larry Freeman, DGGS Minerals Section geologist, compares his notes to observations of polydeformed Casadepaga Schist cropping out along the Nome-Council Highway. A DGGS geologic team mapped and sampled this portion of the southern Seward Peninsula during 2006 to produce a detailed geologic map of the area and to investigate possible lode sources for the abundant placer gold resources of the region. Photo by David Szumigala, DGGS.

D.J. Szumigala and R.A. Hughes
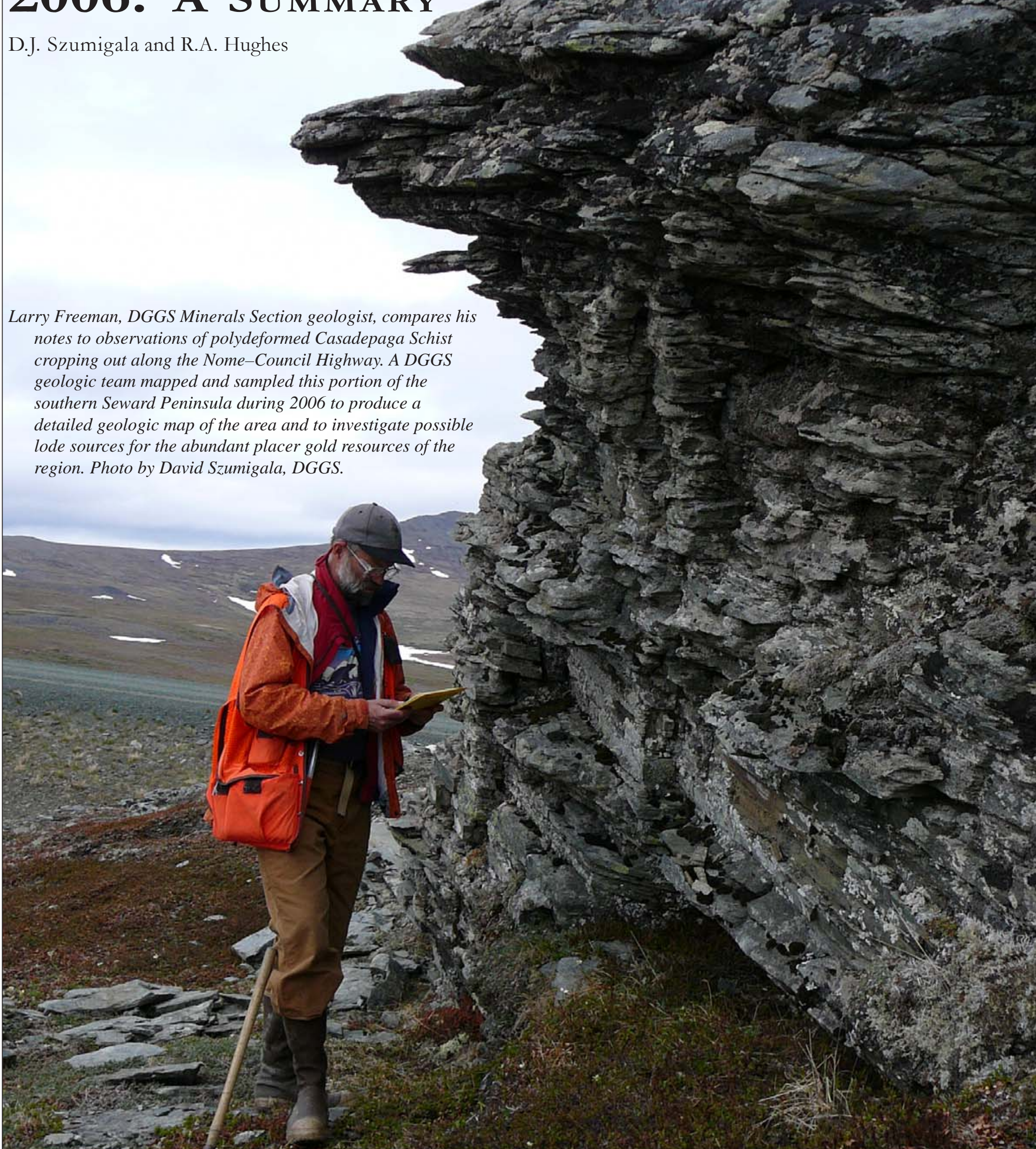



\section{GOVERNOR'S FOREWORD}

Under the Alaska Constitution, one of the fundamental responsibilities of state government is to provide for the wise development of our natural resources for the benefit of the people of our state. As we approach the end of our first half-century under this Constitution, it is a pleasure to know that we are successfully fulfilling this responsibility.

As Governor of Alaska, I am honored to present this report by the Alaska Department of Natural Resources, Division of Geological \& Geophysical Surveys, documenting the continuing strength of Alaska's mineral industry in 2006. Though preliminary, this report tells the clear story of a healthy, growing, and forward-looking sector of our economy whose best days are still to come.

The clearest demonstration of this success rests in the total value of the mineral industry. Its value reached another record high in 2006 of \$3.26 billion. The combined value of the exploration for, and development and production of our mineral resources increased by an astounding 76 percent over the $\$ 1.85$ billion posted the year before, and marks the 11th straight year of \$1 billion-plus value.

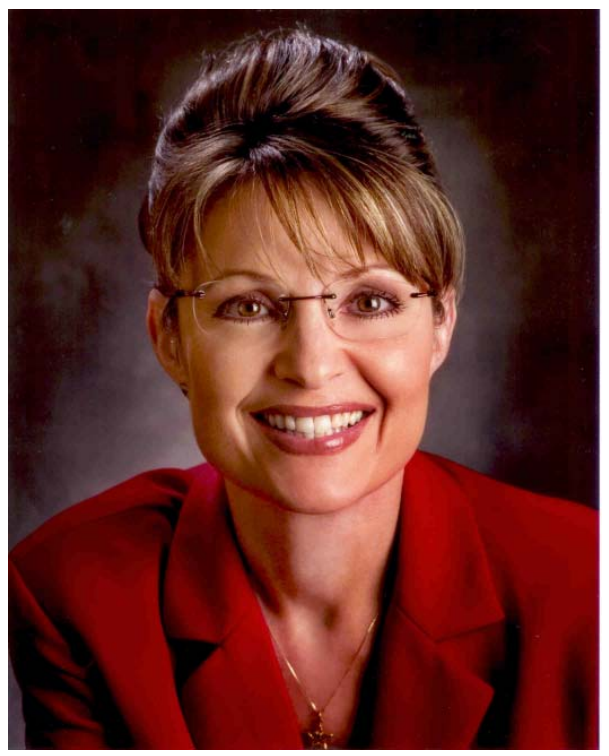
This clearly demonstrates the mineral industry's ongoing status as one of the most important elements of our state's economy.

That record value is attributable primarily to the increased value that the world markets placed on Alaska's mineral products. Our state saw the value of its mineral production nearly double from \$1.4 billion in 2005 to almost \$2.8 billion in 2006, even as the volume of minerals produced decreased slightly. While low prices brought lean years in the past, they also sharpened our miners'ability to compete in a tough environment and to see their fortunes rise along with world metals prices, especially zinc, gold and copper.

The already strong investment in the exploration sector of Alaska's mineral industry rose sharply from \$104 million in 2005 to \$176 million in 2006, with a majority of that investment coming in southwestern Alaska, currently one of the most exciting of Alaska's mineral regions. Overall, investment in exploration extended into all corners of the state, demonstrating the mineral industry's confidence in Alaska as a place where consistent application of sound management principles creates a level playing field for mineral development today, and helps generate new wealth for the future.

The value of mineral development in Alaska demonstrates industry's commitment to transform potential into profits through production. It is gratifying to see that private industry invested \$331 million in 2006 to develop resources and bring them to market, down just 5 percent from \$348 million in 2005. As these significant investments in exploration lead to identification of new deposits, I am confident development expenditures will trend upward again.

In addition to generating revenue for local communities through taxes and business activity, mining has long offered Alaskans the benefit of creating steady jobs that pay among the highest average wages in the state. In 2006, mining generated an estimated 3,014 full-time jobs, an increase of 193 jobs over 2005, many of them in rural areas where residents are eager for career opportunities. As new prospects ramp up around the state, mining should generate even more jobs in the future.

While these production numbers and employment figures are welcome, they cannot measure the new energy and spirit that are suffusing the industry. The men and women who make up Alaska's mining community today carry a hard-won air of energy and optimism that says as much about the quality of their character as it does about the economics of their industry. I am proud of the accomplishments of miners, and of the spirit that makes those accomplishments possible. I wish them continued success as they, and we, look to the future with excitement and confidence.

Sarah Palin

Governor 



\title{
Alaska's Mineral Industry 2006:
}

\author{
A Summary \\ D.J. Szumigala ${ }^{1}$ and R.A. Hughes ${ }^{2}$
}

\section{INTRODUCTION}

Alaska's mineral industry attained a new record value in 2006 due to continued strong metal prices throughout 2006 and steady mineral production. Total value of Alaska’s mineral industry will exceed $\$ 3.26$ billion in 2006, a record value and the eleventh consecutive year above $\$ 1$ billion. Table 1 shows the estimated annual value of the mineral industry in Alaska between 1981 and 2006, as divided between exploration and development investments, and the gross value of the mineral products. These preliminary combined values total \$3.26 billion in 2006, compared to \$1.85 billion in 2005 .

This summary of Alaska's mineral industry activity for 2006 is made possible by information provided through press releases, annual reports, phone interviews, and replies to questionnaires mailed by the Alaska Division of Geological \& Geophysical Surveys (DGGS). The final report will be available later in the year after further compilation of information, particularly for placer mining and industrial minerals. This report is part of a cooperative venture between DGGS and the Division of Mining, Land \& Water (DMLW) in the Department of Natural Resources (DNR) and the Office of Economic Development, Department of Commerce, Community and Economic Development (Commerce). The estimates used in this summary are generally conservative because data have not yet been completely reported. This summary and data contained within it will be superceded by DGGS Special Report 61 to be published later in 2007.

Exploration expenditures rose sharply above robust 2005 levels to more than \$176 million. Twenty-three projects, which extend across the state, had exploration expenditures of $\$ 1$ million or more, and 40 additional projects had exploration expenditures of $\$ 100,000$ or more. Development investment decreased to roughly $\$ 331$ million in 2006, about a \$17 million drop from the 2005 mineral investment value. Mine construction continued at Teck Cominco Inc.-Sumitomo Metal Mining Co.'s Pogo gold project in eastern Alaska and at Coeur Alaska Inc.'s Kensington gold project in southeastern Alaska. Mine construction began at NovaGold Resources Inc.'s Rock Creek project near Nome. Mine rehabilitation and development was completed at St. Andrew
Goldfields Ltd.'s Nixon Fork Mine near McGrath, with the mill commissioned in December.

Production volumes from Alaska's lode mines were level or down compared to 2005. However, continued strong metal prices overcame production shortfalls. Production values amounted to $\$ 2.753$ billion, almost doubling 2005’s value of $\$ 1.402$ billion. Strong zinc prices contributed to a $\$ 1.54$ billion value of Red Dog Mine 2006 production. Ore was fed to the mill at the Pogo Mine on January 12 and the first gold pour was on February 12. The rock, sand, and gravel

Table 1. Total value of the mineral industry in Alaska by year (in millions of dollars U.S.)

\begin{tabular}{|c|c|c|c|c|}
\hline & $\begin{array}{l}\text { Exploration } \\
\text { (expenditure) }\end{array}$ & $\begin{array}{l}\text { Development } \\
\text { (expenditure) }\end{array}$ & $\begin{array}{l}\text { Production } \\
\text { (value) }\end{array}$ & $\begin{array}{c}\text { Total } \\
\text { (calculated) }\end{array}$ \\
\hline 1981 & 76.3 & 24.7 & 188.6 & 289.6 \\
\hline 1982 & 45.6 & 41.6 & 196.4 & 283.6 \\
\hline 1983 & 34.1 & 27.9 & 212.4 & 274.4 \\
\hline 1984 & 22.3 & 53.4 & 199.4 & 275.1 \\
\hline 1985 & 9.2 & 34.1 & 226.6 & 269.9 \\
\hline 1986 & 8.9 & 24.3 & 198.5 & 231.7 \\
\hline 1987 & 15.7 & 100.3 & 202.4 & 318.4 \\
\hline 1988 & 45.5 & 275.0 & 232.2 & 552.7 \\
\hline 1989 & 47.8 & 134.3 & 277.0 & 459.1 \\
\hline 1990 & 63.3 & 14.3 & 533.0 & 610.6 \\
\hline 1991 & 39.9 & 25.6 & 546.5 & 612.0 \\
\hline 1992 & 30.2 & 29.6 & 560.8 & 620.6 \\
\hline 1993 & 30.3 & 27.7 & 448.7 & 506.7 \\
\hline 1994 & 31.1 & 45.0 & 507.5 & 583.6 \\
\hline 1995 & 34.3 & 148.6 & 537.2 & 720.1 \\
\hline 1996 & 44.7 & 394.0 & 590.4 & $1,029.1$ \\
\hline 1997 & 57.8 & 168.4 & 936.2 & $1,162.4$ \\
\hline 1998 & 57.3 & 55.4 & 921.2 & $1,033.9$ \\
\hline 1999 & 52.3 & 33.8 & $1,032.9$ & $1,119.0$ \\
\hline 2000 & 34.9 & 141.7 & $1,106.4$ & $1,283.0$ \\
\hline 2001 & 23.8 & 81.2 & 917.3 & $1,022.3$ \\
\hline 2002 & 26.5 & 34.0 & $1,012.8$ & $1,073.3$ \\
\hline 2003 & 27.6 & 39.2 & $1,000.7$ & $1,067.5$ \\
\hline 2004 & 70.8 & 209.1 & $1,338.7$ & $1,618.6$ \\
\hline 2005 & 103.9 & 347.9 & $1,401.6$ & $1,853.4$ \\
\hline 2006 & 176.5 & 331.0 & $2,752.6$ & $3,260.1$ \\
\hline Total & $1,210.6$ & $2,842.1$ & $18,078.0$ & $22,130.7$ \\
\hline
\end{tabular}

Source: Alaska’s Mineral Industry reports published annually by DGGS/Commerce.

\footnotetext{
${ }^{1}$ Alaska Division of Geological \& Geophysical Surveys, 3354 College Rd., Fairbanks, Alaska 99709-3707

${ }^{2}$ Alaska Office of Mineral Development, 211 Cushman St., Fairbanks, Alaska 99701
} 
industry's reporting is very much behind schedule, with significant apparent shortfalls expected to be reduced by additional information.

\section{EMPLOYMENT}

Table 2 lists estimated employment in the Alaska minerals industry for the past eight years. The total minerals industry employment in 2006 is estimated to be 3,014 fulltime-equivalent jobs, an increase of almost 200 jobs from the estimated 2005 total of 2,821 jobs. With more complete data, especially for the sand and gravel and placer gold mining sectors, the number of 2006 jobs might rise slightly. Most of the employment increase was in the exploration and development sectors. It is expected that the number of jobs in the development sector will decrease for 2007 because the development phase of the Pogo project is nearly complete. The number of jobs will increase significantly in the lode gold production sector as the Pogo Mine begins full commercial production in 2007. Higher gold prices may also spur more placer gold mining and employment.

\section{EXPLORATION}

Exploration expenditures in Alaska during 2006 were at least \$176 million, 68 percent higher than the $\$ 103.9$ million spent in 2005. Figure 1 shows the location of the most significant exploration projects in Alaska during 2006. Increased exploration expenditures in Alaska mirror increased worldwide mineral exploration budgets. The increases in worldwide exploration expenditures resulted from a combination of increased spending by major mining companies, a significant reduction in the negative influence of industry consolidation from peak years 2000 and 2001, and higher spending by junior mining companies in response to stronger gold and base-metal prices. The stronger Canadian dollar and attractive tax incentives for investors in Canada-based projects likely limited even more investment in Alaska.

Twenty-three projects distributed across the state had exploration expenditures of at least $\$ 1$ million, and 40 additional projects had exploration expenditures of $\$ 100,000$ or more. Figure 2 shows 2006 exploration expenditures in Alaska by region. More than $\$ 122.8$ million was spent in southwestern Alaska, with $\$ 11.2$ million spent in eastern Interior Alaska, more than \$12 million spent in western Alaska, \$9.5 million spent in southeastern Alaska, roughly \$9.7 million spent in southcentral Alaska, \$9.8 million spent in northern Alaska, and in excess of \$1 million spent in the Alaska Peninsula region. As in years past, most exploration funds (more than 80 percent) were derived from Canadian sources. At least 715,000 feet of exploration core and rotary drilling were completed in 2006.

Companies explored for a wide variety of mineral deposits in Alaska during 2006. Table 3 lists exploration expenditures by commodity. Gold remained a major exploration commodity, but exploration for copper-gold porphyry systems (grouped with polymetallic deposits) was the major exploration target in 2005. Base-metal exploration expenditures increased significantly from 2003 levels. Platinum-group-element exploration remained steady. Figure 3 shows 2006 Alaska exploration expenditures by

Table 2. Estimated Alaska mine employment, 1999-2006 ${ }^{a}$

\begin{tabular}{|c|c|c|c|c|c|c|c|c|}
\hline & 1999 & 2000 & 2001 & 2002 & 2003 & 2004 & 2005 & 2006 \\
\hline \multicolumn{9}{|l|}{ Gold/silver mining } \\
\hline Placer & 591 & 470 & 176 & 148 & 82 & 64 & 86 & 139 \\
\hline Lode & 296 & 274 & 337 & 413 & 325 & 433 & 411 & 659 \\
\hline Polymetallic mining & 275 & 275 & 275 & 262 & 295 & 265 & 250 & 295 \\
\hline Base Metals mining & 549 & 556 & 559 & 580 & 388 & 508 & 449 & 450 \\
\hline Recreational mining & 240 & 250 & 210 & 180 & 175 & 175 & 175 & 98 \\
\hline Sand \& Gravel mining & 590 & 603 & 556 & 702 & 349 & 567 & 400 & 197 \\
\hline Rock & 128 & 150 & 137 & 177 & 35 & 475 & 148 & 22 \\
\hline Coal & 121 & 121 & 121 & 100 & 65 & 90 & 95 & 95 \\
\hline Peat $^{\text {b }}$ & 38 & 36 & 32 & 21 & 20 & 4 & 6 & 11 \\
\hline \multicolumn{9}{|c|}{ Tin, jade, soapstone, ceramics, } \\
\hline platinum mining & 20 & 20 & 20 & 20 & 20 & 0 & 0 & 0 \\
\hline Mineral development & 135 & 345 & 333 & 135 & 64 & 283 & 498 & 701 \\
\hline Mineral exploration & 183 & 83 & 79 & 86 & 88 & 184 & 303 & 347 \\
\hline TOTAL & 3,166 & 3,183 & 2,835 & 2,824 & 1,906 & 3,048 & 2,821 & 3,014 \\
\hline
\end{tabular}

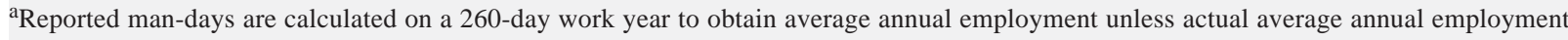
numbers are provided.

bThis figure does not include all of the man-days associated with peat operations; most of those man-days are included in sand and gravel numbers. 
deposit type. About equal amounts were spent on intrusion-related gold deposits (\$66.3 million) and porphyry copper-gold deposits (\$66.4 million). More than \$20 million was spent on various gold-quartz vein deposits, \$18 million was spent exploring for polymetallic massive sulfide deposits, and $\$ 5.7$ million was spent on platinum-group-element ultramafic deposits, epithermal gold deposits, epithermal, uranium deposits, diamond, tin, coal and other deposit types.

Advanced exploration projects include Barrick Gold Corp.-NovaGold Resources Inc.-Calista Corp.'s 28.4million-ounce Donlin Creek intrusion-hosted gold project and Northern Dynasty Minerals Ltd.'s Pebble copper-gold porphyry project in southwestern Alaska. The Pebble project, with newly announced mineral resources of 67 billion pounds of copper, 82 million ounces of gold, and 5.2 billion pounds of molybdenum, was the largest Alaskan mineral exploration project in 2006.

\section{Northern Region}

NovaGold Resources Inc., in joint venture with Rio Tinto Plc, continued exploration at the Ambler Project. NovaGold collected 2,106 stream silt and soil samples and conducted 13 time-domain electromagnetic (TDEM) surveys. Core drilling totaling 9,876 feet in 12 holes was completed at the Dead Creek, Sunshine, Red, and COU prospects. The drilling confirmed additional high-grade copper and precious metal mineralization, with new crosscutting high-grade zinc-lead-copper veins discovered at the Red prospect, about 2 miles east of the Arctic prospect. Exploration work continued on a major geophysical anomaly identified the previous year. Geological studies refined the structural emplacement of the massive sulfide zones in a regional fold belt. An updated resource estimate shows an inferred resource of 1.6 billion pounds of copper, 32.7 million ounces of silver and 0.4 million ounces of gold. NovaGold has significantly expanded its claim holdings in the district to more than 145 square miles.

The 2006 exploration program of the Little Squaw Gold Mining Co. consisted of geological studies and mapping, prospect evaluation on 38 presently known prospects in the Chandalar mining district, and a 7,763-foot reversecirculation drill program that drilled nine prospects. Drill results included a quartz vein intercept on the Eneveloe Prospect of 25 feet of 0.171 ounces of gold per ton, including 5 feet of 0.742 ounces of gold per ton. Drilling results at the Kiska Prospect included a 10-foot intercept in hole KIS 17 of 0.032 ounces of gold per ton. All drill holes that penetrated their targets at the Summit and Little Squaw prospects had gold-bearing intercepts. Assay results confirm continuity of gold mineralization to the depth of drilling, which is 200 feet below surface. Drilling and systematic soil and rock sampling confirm that individual gold-bearing quartz veins and shear zones persist over several thousand feet of strike length. The Summit drill holes (SUM 6 to 12) had 5- to 10-foot mineralized intercepts with values ranging from 0.095 to 0.264 ounces of gold per ton, including a 5 -foot intercept of 0.457 ounces of gold per ton in hole SUM 8. Best results from the Little Squaw drill holes (LS 1 to 5) were 25 feet grading 0.123 ounces of gold per ton, including 5 feet of 0.314 ounces of gold per ton in hole LS 2. Hole LS 5 had a 5-foot intercept

Figure 1. Projects shown on this map represent $\$ 173.9$ million of the \$176.5 million spent on exploration in Alaska during 2006.

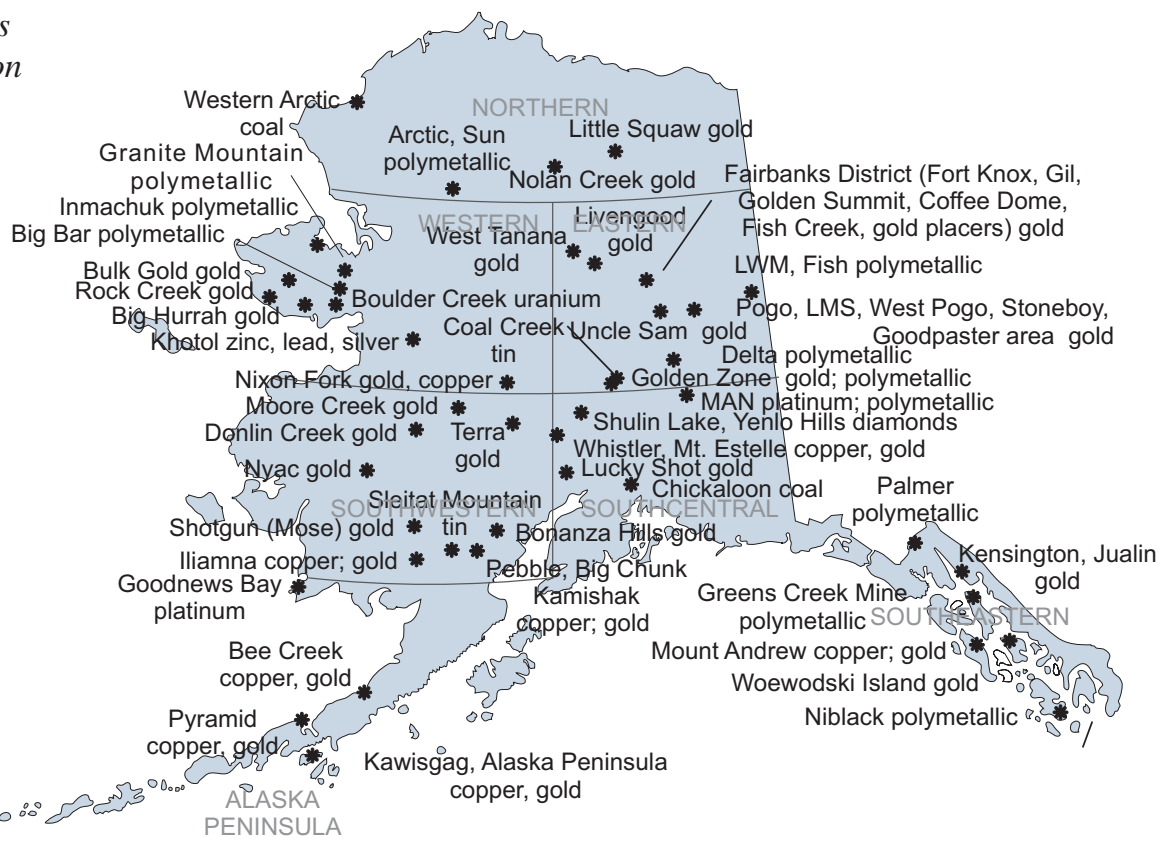


grading 0.1 ounces of gold per ton and the other drill holes had short intercepts of low-grade gold.

A placer gold evaluation of the Little Squaw property indicates excellent potential for additional placer gold deposits in bench placer deposits along Little Squaw Creek. Drilling was recommended to quantify the potential placer gold resources.

Silverado Gold Mines Ltd. dug 920 feet of trench with a backhoe in an area north of Smith Creek on the Nolan Creek property. This area is part of the Solomon Shear, a 5-mile-long gold-bearing shear zone, interpreted by Silverado to be part of the source area of placer gold in the Nolan Creek area. Trenching successfully identified three zones that contain gold-antimony-quartz veins. The "main zone” contained 16 veins over a 190-foot width. Individual gold-antimony-quartz veins vary in width from one-quarter inch to 7 inches. Spacing of veins also varies, from one-quarter inch to several feet. A total of 71 combined chip and channel rock samples were collected during the trenching program and 32 samples had gold values exceeding 0.01 ounces of gold per ton, up to 0.83 ounces of gold per ton. Twelve trench samples had high antimony values ranging from 6.59 to 46.33 percent.

Silverado also drilled one reverse-circulation drill hole north of Smith Creek. Drill hole 06SH01 confirmed the presence of gold-antimony-quartz veins to a vertical depth of 210 feet over a projected horizontal width of 125 feet. Ten of fifty-seven 5-foot samples had gold values greater than 0.01 ounces of gold per ton, ranging up to 0.06 ounces of gold per ton. Antimony values ranged up to 2.51 percent. Silverado also completed 39 reverse-circulation drill holes on the Slisco Bench along the Hammond River for placer gold exploration. All holes penetrated bedrock for a total of 4,782 feet drilled. Samples were processed through an on-site Denver Gold Saver to produce mineral concentrates (sulfides, heavy rock particles, and gold) that were panned and assayed. Drill results confirm the presence of gold in areas of previous drilling and have identified a channel containing placer gold that extends for a length of more than 1,800 feet. The channel remains open to the southeast and there is evidence of one or more tributary channels that remain to be explored. Within the Slisco channel, the placer gold occurs on bedrock and on a second horizon about 20 feet above the bedrock channel. Placer gold pay ranged from 5 to 10 feet thick, with visible gold nuggets and gold grades ranging from 0.009 to 0.495 ounces per bank cubic yard.

Silverado acquired 13 federal placer claims and 237 federal lode claims near the Nolan Creek property, increasing the total claim area to more than 11 square miles. Exploration drilling was also done on Silverado's newly acquired placer claims, in particular the Topnotch prospect. A total of nine holes were drilled, of which two holes yielded placer gold values greater than 0.01 ounces per bank cubic yard for a 5-foot sample. Bedrock is shallow at the Topnotch prospect and potential placer deposits could be accessed by open pit mining.

Andover Ventures Inc. acquired a 50 percent interest in the Sun mining claims in the Ambler District. The purchase price was \$2.6 million and the seller, Hastings Base Metals Corp., retains a 1.5 percent net smelter return. Andover also obtained an option to acquire the remaining 50 percent interest for a purchase price of $\$ 9$ million payable in cash or shares. The Sun Property consists of a total of 25 mining claims with mineralization defined by historical drilling for approximately 2 miles along strike. Mineralization consists of up to three volcanogenic massive sulfide (VMS) horizons up to 38 feet thick. The favorable host rocks are schistose metafelsic volcanic, tuffaceous, and sedimentary rocks occurring in an isoclinally folded linear belt. Andover staked an additional sixty-eight 160 -acre State claims along 10 miles of the highly prospective metavolcanic belt.

Arctic Slope Regional Corp. and BHP Billiton Ltd. signed a series of agreements providing BHP Billiton an exclusive right to explore and possibly develop the coalbearing land held by Arctic Slope Regional Corp. in northwestern Alaska. The Western Arctic region includes
Figure 2. 2006 exploration expenditures in Alaska by region.

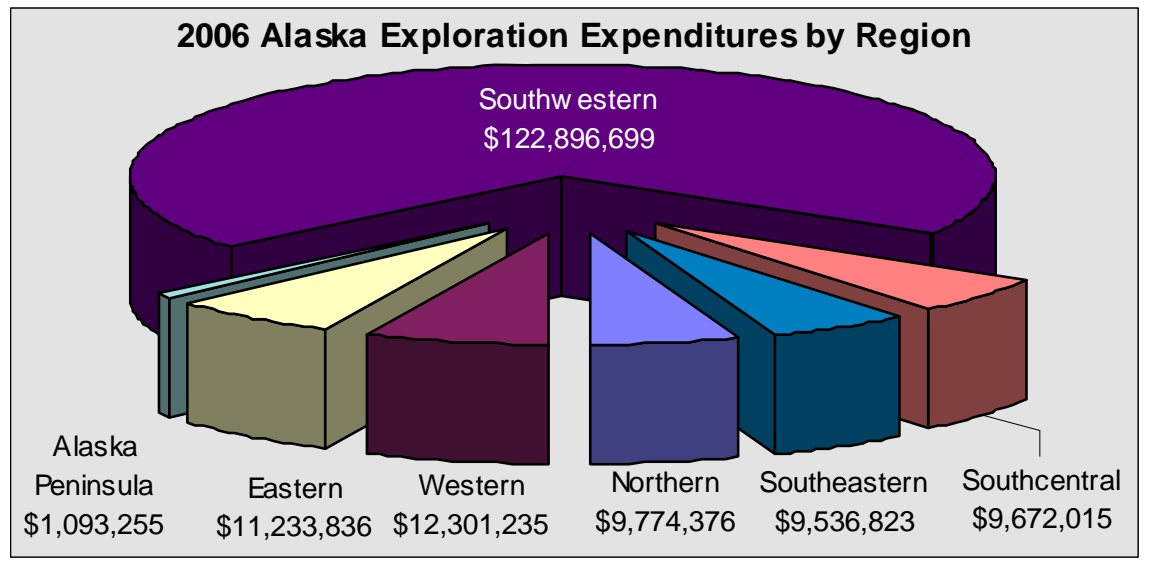


a number of known low-sulfur bituminous coal-bearing areas. BHP Billiton conducted an exploration program inland from the Inupiat communities of Point Lay and Point Hope.

\section{Western Region}

NovaGold Resources Inc. drilled the Big Hurrah property near Nome to include a higher-grade resource in the proposed Rock Creek mine plan. Environmental baseline work continued for the Rock Creek permit process. A total of 32,500 feet of drilling was planned at the Big Hurrah and Rock Creek areas. Limited drilling at Rock Creek occurred along the northern highwall of the deposit and immediate extension of the tension veins farther to the south on the southern margin of the deposit and across the Sophie Gulch fault. A new gold resource calculation estimates indicated resources of 677,000 ounces of gold and an additional inferred resource of 100,000 ounces of gold.
NovaGold also continued exploring the Khotol Project near the Yukon River northeast of the reclaimed Illinois Creek open-pit gold mine. High-grade silver and associated base-metal mineralization occurs as disseminated to massive sulfide replacement-style bodies along a regional dolomitic limestone-quartzite contact. Drilling was planned but no results were announced.

Triex Minerals Corp. (operator) and Full Metal Minerals Ltd. conducted exploration on the Boulder Creek (formerly called Death Valley) project, the largest known uranium deposit in Alaska. The project area is on the southeastern Seward Peninsula. The deposit is a sandstone-type 'roll-front' deposit with predominantly epigenetic mineralization. Uranium was leached from a Late Cretaceous alkalic quartz monzonite intrusion and deposited within a reducing environment of Paleocene, arkosic, carbonaceous conglomerates, and sandstones of the Boulder Creek Basin.

Table 3. Reported exploration expenditures in Alaska by commodity, 1982-2006

\begin{tabular}{|c|c|c|c|c|c|c|c|c|}
\hline \multirow[b]{2}{*}{1982} & \multirow{2}{*}{$\begin{array}{c}\begin{array}{c}\text { Base } \\
\text { metals }\end{array} \\
\$ 31,757,900\end{array}$} & \multicolumn{2}{|c|}{ Polymetallic ${ }^{a}$} & \multirow{2}{*}{$\begin{array}{c}\begin{array}{c}\text { Precious } \\
\text { metals }^{\mathbf{b}}\end{array} \\
\$ 10,944,100\end{array}$} & $\begin{array}{c}\text { Industrial } \\
\text { minerals }\end{array}$ & \multirow{2}{*}{$\begin{array}{c}\begin{array}{c}\text { Coal } \\
\text { and peat }\end{array} \\
\$ 2,900,000\end{array}$} & \multirow{2}{*}{$\begin{array}{l}\text { Otherc } \\
\$ 15,300\end{array}$} & \multirow{2}{*}{$\begin{array}{c}\text { Total } \\
\$ 45,617,300\end{array}$} \\
\hline & & $\$$ & N/A & & - - & & & \\
\hline 1983 & $9,758,760$ & & N/A & $20,897,555$ & $2,068,300$ & $1,338,454$ & 70,000 & $34,133,069$ \\
\hline 1984 & $4,720,596$ & & N/A & $14,948,554$ & 270,000 & $2,065,000$ & 279,500 & $22,283,650$ \\
\hline 1985 & $2,397,600$ & & N/A & $6,482,400$ & - - & 270,000 & - - & $9,150,000$ \\
\hline 1986 & $1,847,660$ & & N/A & $6,107,084$ & 170,000 & 790,000 & - - & $8,914,744$ \\
\hline 1987 & $2,523,350$ & & N/A & $11,743,711$ & 286,000 & $1,150,000$ & 31,000 & $15,734,061$ \\
\hline 1988 & $1,208,000$ & & N/A & $41,370,600$ & 160,200 & $2,730,000$ & - - & $45,468,800$ \\
\hline 1989 & $3,503,000$ & & N/A & $43,205,300$ & 125,000 & 924,296 & 5,000 & $47,762,596$ \\
\hline 1990 & $5,282,200$ & & N/A & $57,185,394$ & 370,000 & 321,000 & 97,000 & $63,255,594$ \\
\hline 1991 & $4,789,500$ & & N/A & $34,422,039$ & 92,000 & 603,000 & 2,000 & $39,908,539$ \\
\hline 1992 & $1,116,000$ & 3,5 & 50,000 & $25,083,000$ & 25,000 & 425,000 & - - & $30,209,000$ \\
\hline 1993 & 910,000 & 5,6 & 76,743 & $23,382,246$ & 163,500 & - & 125,000 & $30,257,489$ \\
\hline 1994 & 600,000 & 8,0 & 99,054 & $18,815,560$ & 225,000 & $2,554,000$ & 810,000 & $31,103,614$ \\
\hline 1995 & $2,770,000$ & 10,5 & 50,000 & $20,883,100$ & 100,000 & - & 3,000 & $34,306,100$ \\
\hline 1996 & $1,100,000$ & 11,9 & 33,364 & $31,238,600$ & 400,000 & - & - - & $44,721,964$ \\
\hline 1997 & $1,700,000$ & 22,3 & 47,000 & $32,960,500$ & 80,000 & 720,000 & - & $57,807,500$ \\
\hline 1998 & $1,000,000$ & 13,7 & 27,000 & $42,441,000$ & 12,000 & 87,000 & - - & $57,267,000$ \\
\hline 1999 & $3,869,000$ & 3,1 & 58,000 & $44,891,000$ & 1,000 & - - & 410,000 & $52,339,000$ \\
\hline 2000 & $8,545,000$ & 3,9 & 33,000 & $21,579,000$ & 58,500 & - - & 736,100 & $34,851,600$ \\
\hline 2001 & $4,810,000$ & 1,9 & 77,000 & $15,820,000$ & 50,000 & 10,000 & $1,106,000$ & $23,773,000$ \\
\hline 2002 & $1,700,000$ & 5,1 & 52,000 & $17,342,000$ & 185,000 & - - & $2,113,000$ & $26,502,000$ \\
\hline 2003 & 262,000 & 7,0 & 31,000 & $19,726,000$ & - - & W & 533,000 & $27,602,000$ \\
\hline 2004 & $3,100,000$ & 40,2 & 37,000 & $26,954,000$ & 213,000 & 50,000 & 258,000 & $70,812,000$ \\
\hline 2005 & $1,764,000$ & 54,2 & 71,000 & $46,255,000$ & 142,000 & - - & $1,413,000$ & $103,845,000$ \\
\hline 2006 & $3,816,056$ & 80,5 & 20,009 & $89,141,890$ & 20,000 & 479,945 & $2,397,118$ & $176,451,974$ \\
\hline Total & $\$ 133,112,822$ & $\$ 272,2$ & 2,170 & $\$ 759,092,833$ & $\$ 15,516,500$ & $\$ 19,758,695$ & $\$ 10,531,018$ & $1,210,380,994$ \\
\hline
\end{tabular}

aPolymetallic deposits considered a separate category for the first time in 1992.

${ }^{b}$ Approximately $\$ 1.9 \mathrm{M}$ spent on platinum-group-element exploration during 2006 (\$4.0M in 2005, \$3.3M in 2004, \$2.4M in 2003,

$\$ 650,000$ in 2002).

'Includes diamonds and tantalum.

N/A = Not available.

- - Not reported.

$\mathrm{W}=$ Withheld, data included in "Other" column. 
Fourteen core holes totaling 4,058 feet were completed in 2006 within and peripheral to the known limits of mineralization. Two holes completed in the core of the deposit confirmed the historic grade and thickness of the deposit. Hole DV06-54, in the core of the northern part of the deposit, contained 0.32 percent U3O8 over 20 feet between 75 and 95 foot depth, including 0.87 percent U3O8 over 6.5 feet. Hole DV06-64 contained 0.32 percent U3O8 over 6.5 feet within 16.4 feet of 0.17 percent U3O8 between 37.4 and 53.8 foot depth. Possible extensions of the deposit along strike to the north and south were not thoroughly explored. Two holes were completed at Carbon Creek, about 4.3 miles northwest along strike from the main deposit at Boulder Creek. These holes did not intersect significant uranium mineralization, but favorable host stratigraphy was confirmed. Extensive reconnaissance exploration in the Boulder Creek and McCarthy Marsh regions, including 1,862 line-miles of airborne radiometrics and collection of 475 rock, soil, and biogeochemical samples, successfully identified multiple new targets for detailed evaluation and potential drill-testing in 2007.

Mystery Creek Resources Inc., a subsidiary of St. Andrew Goldfields Ltd., continued exploration on the Nixon Fork gold-copper skarn property near McGrath. An underground winter 2006 diamond drilling program at the Mystery Creek deposit completed 11,484 feet of core drilling to delineate and confirm additional ore zones that will provide feed for the planned Nixon Fork mining operations.

Linux Gold Corp. continued exploring in the Granite Mountain area of the Seward Peninsula. Soil sample grids were completed on the Gossan Ridge subvolcanic goldsilver-copper prospect, the Quartz Creek plutonic gold-bismuth prospect, and the Saddle lead-silver-zinc vein prospect. Reconnaissance exploration was conducted on the Peace molybdenum-uranium vein prospect, with analytical results ranging from 0.059 to 0.116 percent molybdenum. A drilling program of four core holes totaling 2,971 feet tested four mineralized zones on the Granite Mountain property. A total of 595 core samples, 640 soil samples, 61 rock samples, and five heavy mineral samples were collected and submitted for geochemical analysis. Geochemical results from rock and soil samples indicate new gold anomalies at the head of the Kiwalik River and on the lower reach of Quartz Creek. Drilling verified basemetal mineralization at the Saddle Prospect, with a 35-foot intercept in hole KW06-03 from 70 to 105 foot depth averaging 0.24 percent lead, 0.94 percent zinc, and 0.15 ounces of silver per ton. Stibnite-rich zones were found in drilling at the Quartz Creek prospect and the best intercept was 10 feet averaging 0.008 ounces of gold per ton and 0.27 ounces of silver per ton. Pan samples of alluvial deposits at Dime Creek revealed high-grade placer gold and platinum concentrations, as well as uranium at the head of
Figure 3. 2006 Alaska exploration expenditures by deposit type.

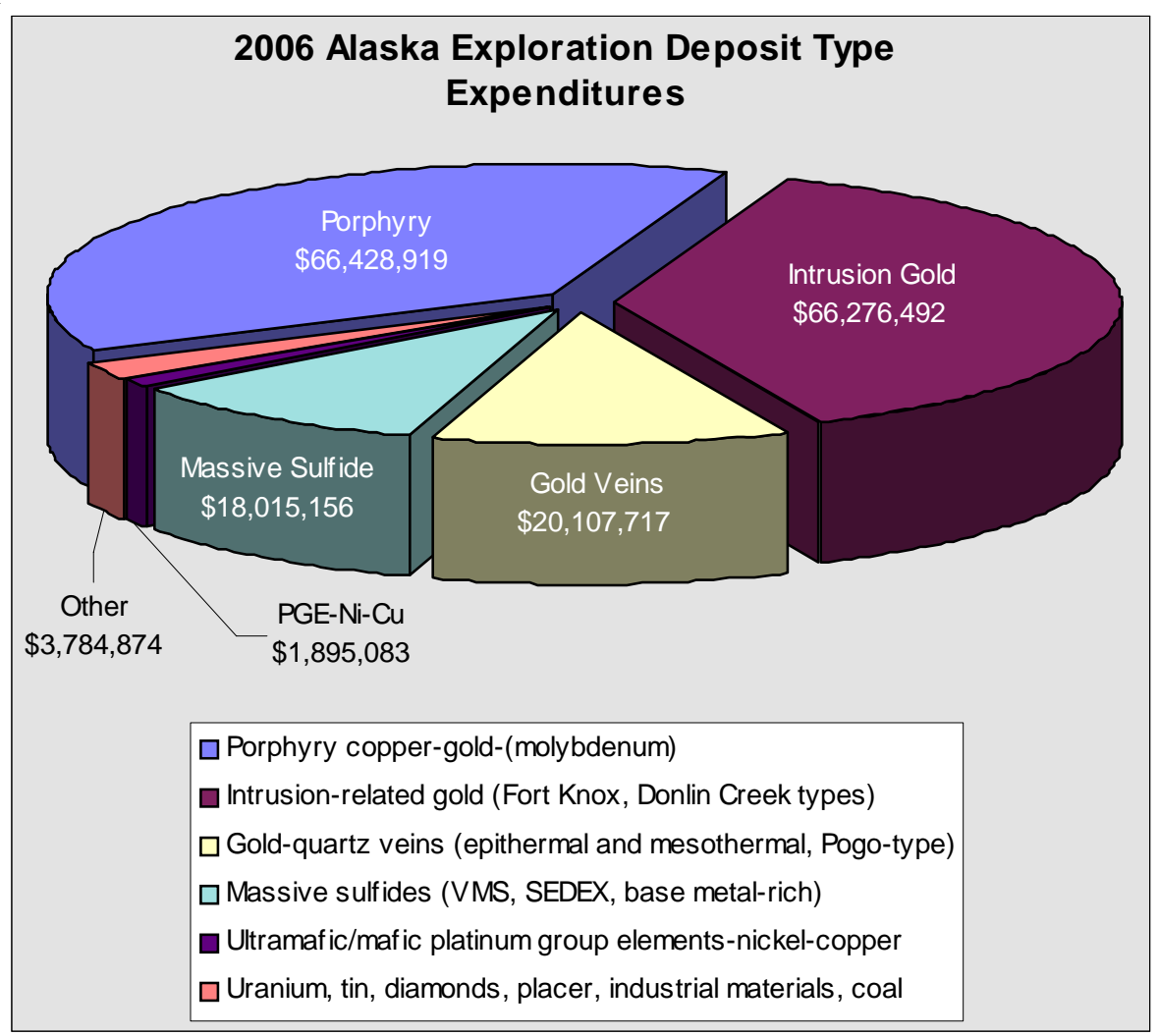


Quartz Creek. Linux staked an additional 136 mining claims in the area for a total claim block of 68 square miles.

Quaterra Resources Inc. drilled the Big Bar copperlead-zinc prospect on the Seward Peninsula. The 1,470-foot drilling program targeted a 4,000-foot-long soil anomaly. The anomaly contains up to 0.19 percent copper in felsic schist that corresponds to gravity and induced polarization (IP) geophysical anomalies. Gossan samples collected as float from the anomalous area contain up to 0.002 ounces of gold per ton, 1.45 ounces of silver per ton, 0.43 percent copper and 0.39 percent zinc. Drill holes BB06-1 and BB06-2 encountered an upper mineralized section in pervasively sericite-altered metavolcanic rock of upper greenschist to lower amphibolite metamorphic grade. Sulfide mineralization occurred in long intercepts of 1 to 5 percent sulfides, with disseminated and stringer pyrite and pyrrhotite and possible chalcopyrite in the upper 200 feet of the drilled section. Sulfide content was greatest in the top 100 feet and generally decreased downhole. No massive sulfides were encountered. Both holes appear to have tested a pyritic volcanogenic sulfide system that is either weak or distal to a vent. Assay results from the drilling program indicate that mineralization in each of the holes is subeconomic and does not extend to depth. Hole BB06-1 assayed 0.56 percent copper, 0.02 percent zinc, 0.02 percent lead, with trace amounts of gold and silver from the surface to a depth of 26 feet. Hole BB062 assayed 0.05 percent copper, 0.04 percent zinc, anomalous lead, and trace amounts of gold and silver from the surface to a depth of 46 feet. Mineralization in hole BB06-3 was restricted to the upper part of the hole with 0.46 percent copper, 0.03 percent zinc, 0.02 percent lead and trace amounts of gold and silver from the surface to a depth of 7 feet.

Andover Ventures Inc., in an option agreement with Altar Resources Alaska, completed an eight-hole HQ core drilling program at the Big Pig target on the Bulk Gold project north of Nome. Two holes intersected sulfide mineralization consistent with mineralization encountered in a previous vertical core hole. Hole 06BGDH-5 intersected 40.5 feet of disseminated pyrite-arsenopyrite-stibnite mineralization from 23 feet to 63.5 foot depth. Sulfides occur as disseminated grains in schist, meta-granite, altered and brecciated carbonate and within and along thin quartz-feldspar-carbonate veinlets. Hole 06BGDH-8 also intersected similar sulfide mineralization from 169.5 feet to 188.8 foot depth. Holes 06BGDH-6 and 06BGDH-7 were terminated at 19 and 29 feet, respectively, in a barren marble horizon believed to be stratigraphically below mineralization.

Full Metal Minerals Ltd. entered into an agreement with Royal Pretoria Gold Ltd. to acquire 100 percent interest in the Inmachuck gold property. The property is road accessible from the town of Deering on the northern Seward Peninsula. Mineralization types present include structur- ally-controlled gold and silver-lead-zinc prospects. Full Metal mapped and collected 14 rock, 501 soil, 29 silt, and 453 mobile-metal-ion (MMI) samples. Full Metal also completed initial reconnaissance mapping and sampling at the Moore Creek intrusion-related gold prospect near McGrath. No exploration was conducted on the Ganes Creek gold property during 2006 after Fury Explorations Ltd. dropped its option.

Altar Resources drilled nine core holes on the Divide gold property north of Nome, but no results were announced. Placer gold exploration continued on several properties across the region. NovaGold conducted the most extensive work and updated the placer gold resource at its Nome operations to 1.5 million ounces of measured and indicated placer gold ounces.

\section{Eastern Region}

Teck Cominco Inc. continued gold exploration on the Pogo property along the 8-mile-long trend of surface showings. More than 35,000 feet of core drilling was completed at the West Knoll, South Pogo, 4021, Cholla Ridge, Chorizo, Spring Grid, and Tam Ridge areas. No results were announced.

Rimfire Minerals Corp. conducted a mapping and reconnaissance geochemical silt sampling survey over the extensive land package (more than 182,800 acres) acquired by staking in the Goodpaster district. No results were announced. Copper Ridge Explorations Inc. also worked on the Ogopogo property in the Goodpaster area; several smaller projects were also ongoing.

International Tower Hill Mines Ltd., and its whollyowned Alaska subsidiary, Talon Gold Alaska Inc., acquired all Alaskan mineral exploration properties and associated databases from AngloGold Ashanti (USA) Exploration Inc. Tower Hill also made a joint-venture agreement with AngloGold to earn a 60 percent interest in the LMS property. A total of 9,022 feet of core was drilled in eight holes. Drilling expanded the previously defined breccia-hosted Camp Zone mineralization, tested its lateral extents and established structural controls on the high-grade gold veins. Soil geochemical sampling defined new targets along the mineralized trend. Significant drill intercepts include 18.7 feet grading 0.08 ounces of gold per ton and 0.47 ounces of silver per ton in hole LM-06-36, which was a 560-foot step out from earlier drilling. In addition, high-grade zones were expanded with intercepts of 5.6 feet grading 0.35 ounces of gold per ton and 1.72 ounces of silver per ton in hole LM-06-31 and 1 foot grading 2.01 ounces of gold per ton and 0.55 ounces of silver per ton in hole LM-06-25.

Tower Hill acquired the Livengood project from AngloGold in August and then leased an additional 169 mining claims in the area from private parties. Tower Hill drilled 4,000 feet of core in seven holes. Higher-grade gold mineralization in quartz-arsenopyrite veinlets associated 
with a subvolcanic igneous breccia was intersected in hole MK-06-07, with 310.4 feet grading 0.05 ounces of gold per ton. Gold mineralization in igneous and metasedimentary rocks intersected in holes MK-06-05, MK-06-06 and MK-06-08 ranged from 0.01 to 0.02 ounces of gold per ton over widths from 16.4 to 95.1 feet.

Tower Hill also acquired the Coffee Dome, Giles, West Pogo, Chisna, and Blackshell properties in its deal with AngloGold. Tower Mines conducted rock and soil sampling on these properties. At the Blackshell property, sampling confirmed the presence of vein-style gold mineralization hosted within a porphyritic phase of a multiphase intrusive complex. Significant gold mineralized veins have been found over a 0.75-square-mile area. Results from sampling on the Chisna property indicate that a 9.6-square-mile area in the central portion of the property has the potential to host a near-surface bulk tonnage copper-gold-silver deposit. A total of 73 rock samples collected from this area averaged 0.1 percent copper, 0.01 ounces of gold per ton and 0.08 ounces of silver per ton, with 21 of these samples averaging 0.6 percent copper, 0.03 ounces of gold per ton and 0.24 ounces of silver per ton. The average values of 87 soil samples taken on the project are 230 ppm copper, $31 \mathrm{ppb}$ gold and $0.5 \mathrm{ppm}$ silver, with a range from 31 to 1,955 ppm copper, 2 to 255 ppb gold and 0.1 to $2.4 \mathrm{ppm}$ silver.

Tower Hill made an exploration option/mining lease agreement with Doyon Ltd. for the West Tanana property, about 50,000 acres of Doyon-controlled land along the Yukon River. Tower Hill collected 480 soil samples on the West Tanana property and outlined a large gold-arsenicbismuth-tellurium anomaly adjacent to Monday Creek. Gold values in soil samples range from 3 ppb to $1.01 \mathrm{ppm}$. Regional prospecting was also conducted in the Racine Creek area.

Full Metal signed an exploration agreement with Doyon Ltd. for 810,737 acres of lands in the Fortymile area. Full Metal further delineated massive sulfide mineralization on the Little White Man (LWM) and Fish prospects. Diamond drilling at LWM targeted a gravity high identified during a ground-based survey, coinciding with a 1-mile by 1,200foot, zinc-silver-lead soil anomaly defined by 92 soil samples. A total of seven historic grab samples of gossan recovered from pits dug into the soil averaged 5.0 percent zinc, 11.85 percent lead, 0.5 percent copper and 3.08 ounces of silver per ton. Hole LWM06-01 intersected coarsegrained, banded massive pyrite, chalcopyrite, sphalerite, and galena at 100-foot depth hosted within brecciated and locally silicified argillite with altered felsic dikes or flows. Mineralization is interpreted to be a gently dipping massive sulfide body, with 39.7 feet of 3.24 ounces of silver per ton, 0.32 percent copper, 4.0 percent lead, and 15.7 percent zinc, including 21.7 feet grading 5.86 ounces of silver per ton, 0.56 percent copper, 7.2 percent lead, and
27.0 percent zinc and a 10.8 -foot section of massive sphalerite averaging 43.7 percent zinc.

Seven drill holes were also completed at the nearby Fish Prospect, approximately 3.5 miles east of the LWM prospect. Drilling tested an extensive 50- to 75-foot-thick gossan interpreted be derived from intensely weathered massive to semi-massive sulfides with zoned zinc-, silver, gold-, lead-, and copper-rich sections. The gossan was traced by previous workers for 4,900 feet along strike and 820 feet downdip with 71 rock samples averaging 4.5 percent zinc, 0.1 percent lead and 0.33 ounces of silver per ton. Drilling over a 1,600-foot strike length encountered strongly oxidized massive sulfide mineralization including 12.3 percent zinc over 29.5 feet in hole Fish 06-06 and 9.0 percent zinc over 35.8 feet in hole Fish 06-05. Hole Fish 06-06 encountered primary massive sulfide mineralization (26.9 feet grading 0.03 ounces of gold per ton and 3.47 ounces of silver per ton) starting at 679.5 feet below surface. The thickest mineralized intercepts are 145.7 feet grading 1.00 ounces of silver per ton, 0.10 percent copper, 0.09 percent lead, and 3.3 percent zinc in hole Fish 06-05, 92.2 feet grading 0.007 ounces of gold per ton, 0.24 ounces of silver per ton, 0.08 percent copper, and 4.9 percent zinc in hole Fish 06-06, and 67.6 feet grading 1.52 ounces of silver per ton, 0.06 percent copper, 0.08 percent lead, and 1.7 percent zinc in hole Fish 06-07. Mineralization remains open to the south, north, and at depth.

Kinross Gold Inc. continued an exploration drilling program in and around the existing Fort Knox open-pit gold mine near Fairbanks. Kinross also drilled geophysical anomalies at the Last Chance Creek area on the nearby Gil gold property held in joint venture with Teryl Resources Corp. Kinross completed 1,820 feet of reverse-circulation drilling and collected 76 soil and rock samples on the Gil property. The best drill results were from siliceous quartzite intersected in hole GVR06-496, with the interval from 120 - to 125 -foot depth assaying 0.0185 ounces of gold per ton and the interval from 560 to 565 feet assaying 0.0612 ounces of gold per ton.

Freegold Ventures Ltd. discovered new high-grade gold veins in a 4,700-foot trenching program at its Golden Summit property near Fairbanks. Ten trenches near the historic Beistline Shaft tested the eastern extension of the historic Cleary Hill underground mine and to the west six trenches were completed over the Wackwitz Vein and three trenches were completed on the Colorado Vein to further delineate veins and shear zones discovered last fall. Results from trenching in the Beistline Shaft area include 185 feet of strike length of a 4-inch- to 18-inch-wide quartz vein grading 1.15 ounces of gold per ton, including a 75-foot section grading 2.4 ounces of gold per ton. A new 5-foot-wide zone of the Wackwitz Vein averaged 0.48 ounces of gold per ton over 235 feet, including 85 feet grading 1.01 ounces of gold per ton and 50 feet grading 1.5 ounces of gold per 
ton. A new 10- to 15-foot-wide shear zone, named the Currey Zone, was discovered 50 feet south of the Wackwitz Vein and samples over 220 feet of strike length averaged 0.065 ounces of gold per ton. A 10,000-ton bulk sample was collected from nine locations on the property to be processed in the spring of 2007. Construction of a new haul road to transport the bulk mined material exposed new veins, and additional cross-trenching in the area led to the discovery of a number of new veins and shear zones to the south of the Cleary Hill vein system. The Cleary Hill vein system was also trenched approximately 1,200 feet west of the Beistline shaft area, directly above the old underground workings. A 25,000-foot reverse-circulation drill program began in December to test mineralization in the quartz vein swarms by a series of shallow drill holes in a series of fences.

Midas Resources Ltd., through its subsidiary Genesee Gold Mines LLC, explored the Uncle Sam property as part of a joint-venture agreement with Geoinformatics Exploration Inc. Five out of seven reverse-circulation drill holes intersected gold mineralization including 40 feet grading 0.04 ounces of gold per ton starting at 189.6 foot depth and 20 feet grading 0.03 ounces of gold per ton starting at 305-foot depth. Gold mineralization was found in quartz stockwork veins with pyrite, arsenopyrite, stibnite, and pyrrhotite in sericite-altered quartz mica schist. The two unmineralized drill holes were also the holes farthest from the granite intrusion, suggesting that grade is increasing toward the granite contact. All holes intersected a major structure and the downdip projection of this structure is interpreted to intersect a granite intrusion at a depth of 650 feet. This structural style is interpreted to be very similar to the structural setting of a Fort Knox type gold deposit.

Other exploration programs were conducted by Pathfinder Mineral Services in the Stone Boy Creek area near Pogo and Usibelli Coal Mine Inc. near Healy. Rhyolite Resources Ltd., in an option agreement with Grayd Resource Corp., conducted geologic mapping, rock sampling, and a gravity geophysical survey on the Super Cub area of the Delta property near Tok. DGGS contracted an airborne geophysical survey over much of the Bonnifield mining district, with a mid 2007 expected release date of the data. Minor placer gold exploration occurred on numerous properties across the region. One of the largest programs was a stripping and bulk sampling program conducted by Northridge Exploration on American Creek in the Hot Springs mining district.

\section{Southcentral Region}

Kennecott Exploration Co. continued exploring copper-gold targets on the Whistler property near Rainy Pass. An extensive core drilling program was continued, but no results were announced. Kennecott has identified at least eight targets similar to the Whistler prospect in the sur- rounding area. Hidefield Gold Plc. and other companies explored polymetallic mineralization related to composite alkalic intrusions of late Cretaceous age in the Mt. Estelle area to the west of Kennecott's Whistler property.

Hidefield, in a joint-venture agreement with Piper Capital Inc., also continued exploring the Golden Zone gold-silver-copper deposit. Reverse-circulation and core drilling were conducted in the Golden Zone breccia and several of the surrounding prospects. Geochemical sampling, an induced polarization (IP) geophysical survey, and 5,000 feet of trenching were also conducted on portions of the property.

Full Metal Minerals continued exploring the historic Lucky Shot gold mine property in the Willow Creek mining district. The property has excellent access to roads, infrastructure, and power. Gold-bearing quartz veins and structures at Lucky Shot occur within a granitoid batholith. A total of 73 drill holes and 41,672 feet of drilling were completed on the Lucky Shot property in 2006, with drilling focused on the Coleman block portion of the Lucky Shot shear zone and eight holes in the Nippon vein. Some drill results include hole C06-16 with 1.50 ounces of gold per ton over 15.1 feet, hole C06-19 with 3.93 ounces of gold per ton over 3.9 feet, hole C06-21 with 1.76 ounces of gold per ton over 8.2 feet, hole C06-23 with 0.96 ounces of gold per ton over 11.5 feet, hole C06-39 with 4.51 ounces of gold per ton over 1.3 feet, hole C06-60 with 0.34 ounces of gold per ton over 16 feet, hole C06-80 with 0.69 ounces of gold per ton over 5.6 feet, and hole C06-81 with 2.41 ounces of gold per ton over 5.6 feet. All intercepts are estimated true widths. The fault-offset northern extension to the Lucky Shot shear, named the Murphy Block, was discovered by drilling in the Craigie Creek valley and extends the strike length of the Lucky Shot shear to at least 5,900 feet.

Anglo American Exploration (USA) Inc. explored the 150-square-mile Area 1 (Fish Lake-Dunite Hill Area) of Nevada Star Resource Corp.'s 271-square-mile MAN property. Anglo American completed one core drill hole near the base of the Fish Lake Complex near 2005 drill hole 8 and two holes in the Tres Equis area. Drilling results were not announced, but Anglo American withdrew from the MAN project in August after spending in excess of \$3 million over the past two years.

A joint venture between Golconda Resources Ltd., Shulin Lake Mining Co., and Shear Minerals Ltd. continued exploring the Shulin Lake property for diamonds with a four-hole core drilling program in early 2006. The first two holes went through 200 feet of volcanic ash into underlying Tertiary sandstone. Hole 3 collapsed and was abandoned at a 313 foot depth in a chaotic mixture of unconsolidated sand, gravel, and boulders. The last 10 feet of hole 3 contained pieces of possible welded tuff, a rock type not seen in previous drilling. Hole 4 was abandoned 
at 200 feet in unconsolidated material. All previous drill holes had a glacial till layer between zero and about 30 feet thick. The large amount of unconsolidated, unsorted debris in this year's holes and possible welded tuff suggest close proximity to the feeder zone of this volcanic material. The last ten feet of hole 3 were sampled for diamonds and diamond indicator minerals, but no analytical results were announced.

Diamond Gold Corp. also explored for diamonds and other precious stones on their placer and lode properties in and near the Yenlo Hills. Diamond Gold drilled and hand mined 1,000 pounds of possible diamond-bearing rocks, interpreted to be lamproite pipes and dikes, in the headwaters of Sable Creek. Diamond Gold announced the recovery of a microdiamond (106 microns) by caustic fusion from a previous sample. Thirty-three pan concentrates were collected from Sable and Crystal creeks and one possible macro diamond was recovered. A sulfide body was also drilled in the northern Yenlo Hills and drilling intercepted 7 feet of quartz-carbonate-sulfide veinlets from 65 to 72 feet.

Full Metal was awarded a coal lease by the Alaska Mental Health Land Trust that covers 22,647 acres in the Chickaloon portion of the Matanuska Coal Field. The lease area includes Alaska's only known significant occurrences and past-producing operations of metallurgical coal. In October 2006, Afognak Native Corp. entered into an agreement with Full Metal to earn an interest in the Chickaloon project. Full Metal has begun permitting for a drilling program starting in May 2007.

Brett Resources Inc. staked and drilled the Coal Creek tin prospect, with four core holes totaling 2,390 feet. Three holes intersected cassiterite, arsenopyrite, and sphalerite in sheeted greisen bodies along an elongate granite porphyry stock. Hole Coal 06-43 graded 0.13 percent tin, 0.10 ounces of silver per ton, and 0.154 percent zinc from 390 to 775 -foot depth, hole Coal $06-45$ graded 0.08 percent tin, 0.12 ounces of silver per ton, and 0.13 percent zinc from 10.5- to 662-foot depth, and hole Coal 06-46 graded 0.10 percent tin, 0.19 ounces of silver per ton, and 0.07 percent zinc from 87- to 338.5-foot depth.

Full Metals optioned and staked claims comprising the Golddigger property in the Talkeetna Mountains. Limited exploration was completed on the King, Queen, Toklat, and Talkeetna prospects.

Minor placer gold exploration occurred across the region.

\section{Southwestern Region}

Northern Dynasty Minerals Ltd. conducted the largest exploration project in Alaska during 2006 at the Pebble project near Lake Iliamna. The project consists of 1,331 State of Alaska mining claims over copper-gold-molybdenum porphyry mineralization in calc-alkalic porphyry stock(s) and sedimentary host rocks with quartz stockwork veins containing principally pyrite, chalcopyrite, and molybdenite. Previous work on the Pebble project defined the 4.52-billion-ton near-surface Pebble West deposit and the deeper but higher grade 1.98-billion-ton Pebble East deposit. Northern Dynasty continued preliminary engineering activities and environmental and socioeconomic studies and completed 74,000 feet of core drilling in 19 holes (numbered 6338 through 6356). Drilling was focused on determining the overall size, copper-gold-molybdenum grade distribution, and geometry of the world-class Pebble East deposit. Drill holes intersected long intervals of highgrade copper-gold-molybdenum mineralization, substantially expanding the Pebble East deposit beyond the boundaries of the previously announced resource. The north-south strike length of the Pebble East deposit has been extended to more than 7,000 feet, with grades consistently exceeding 1 percent copper equivalent. The deposit remains open to the north and south across a width exceeding 4,000 feet. Importantly, significant amounts of high-grade copper minerals (predominantly bornite) were intersected in the northern- and southern- most holes drilled. The presence of significant bornite mineralization in these holes suggests their proximity to mineralizing centers. Highlights from the drilling include hole 6338 intersecting 1,225 feet grading 1.29 percent copper equivalent comprising 0.45 percent copper, 0.03 ounces of gold per ton, and 0.040 percent molybdenum; hole 6339 intersecting 2,051 feet grading 1.32 percent copper equivalent $(0.84$ percent copper, 0.01 ounces of gold per ton, and 0.032 percent molybdenum); hole 6348 intersecting 949 feet grading 1.92 percent copper equivalent (1.24 percent copper, 0.02 ounces of gold per ton, and 0.042 percent molybdenum); hole 6354 intersecting 705 feet grading 1.52 percent copper equivalent (1.23 percent copper, 0.008 ounces of gold per ton, and 0.020 percent molybdenum); and hole 6355 intersecting 2,252 feet grading 1.28 percent copper equivalent ( 0.70 percent copper, 0.015 ounces of gold per ton, and 0.046 percent molybdenum).

During 2006 Kennecott Canada Exploration Inc. acquired a 9.9 percent interest in Northern Dynasty and increased that to a 19.79 percent interest in January 2007. Northern Dynasty announced a mineral resource estimate for the Pebble East deposit in early 2006 and then increased those resources by nearly 90 percent with a revised resource estimate in January 2007. At a 0.60 percent copper equivalent cutoff, as defined by Northern Dynasty, the estimated inferred mineral resources in the Pebble East deposit are 3.75 billion tons grading 1.00 percent copper equivalent ( 0.57 percent copper, 0.0105 ounces of gold per ton, and 0.036 percent molybdenum), containing 42.6 billion pounds of copper, 39.6 million ounces of gold, and 2.7 billion pounds of molybdenum. At a 1.00 percent copper equivalent cutoff, the estimated inferred mineral 
resources are 1.54 billion tons grading 1.29 percent copper equivalent ( 0.79 percent copper, 0.013 ounces of gold per ton, and 0.039 percent molybdenum), containing 24.6 billion pounds of copper, 20.9 million ounces of gold, and 1.2 billion pounds of molybdenum. The combined resources of the Pebble West and East deposits constitute one of the most significant metal accumulations in the world.

Barrick Gold Corp., after its merger with Placer Dome Inc., continued an extensive drill program on the Donlin Creek Project near Aniak to progress to a completed feasibility study in November 2007. Barrick's joint-venture partners are NovaGold Resources, Calista Corp., and the Kuskokwim Corp. Eight diamond core drill rigs completed 304,500 feet of infill drilling. Drilling focused on converting inferred gold resources to measured and indicated gold resources. More than 33,000 feet of the drilling footage was completed for geotechnical testing, facilities condemnation, limestone resource definition, and metallurgical studies. Analytical results are not yet available for much of the late drilling, but NovaGold Resources released some drilling highlights. Drilling highlights from the Acma area include hole DC06-1129 with 13 mineralized intervals totaling 571 feet grading 0.09 ounces of gold per ton; hole DC06-1130 with 13 mineralized intervals totaling 702 feet grading 0.08 ounces of gold per ton; hole DC06-1131 with 12 mineralized intervals totaling 554 feet grading 0.12 ounces of gold per ton; and hole DC06-1133 with 14 mineralized intervals totaling 843 feet grading 0.11 ounces of gold per ton. Drill highlights from the Lewis area infill drilling include hole DC06-1255 with 7 mineralized intervals totaling 358 feet grading 0.23 ounces of gold per ton; hole DC06-1283 with 13 mineralized intervals totaling 335 feet grading 0.12 ounces of gold per ton; hole DC06-1287 with 15 mineralized intervals totaling 413 feet grading 0.106 ounces of gold per ton; and hole DC06-1376 with 12 mineralized intervals totaling 341 feet grading 0.10 ounces of gold per ton. In addition, drilling showed that the Akivik, Aurora, Acma, East Acma, Vortex, Lewis, and South Lewis prospects remain open laterally and at depth.

NovaGold contracted SRK Consulting (U.S.) Inc. to complete a preliminary economic assessment of the Donlin Creek project. The study confirmed the economics of a conventional open-pit mining operation at a production rate of 66,000 tons per day with the potential to produce on average 1.4 million ounces of gold per year over a 22-year life of the project at a cash cost of $\$ 276$ per ounce of gold. SRK also estimated that the Donlin Creek property contains a measured and indicated resource of 16.6 million ounces of gold and an inferred resource of 17.1 million ounces of gold. The estimate was based on a cutoff grade of 0.022 ounces of gold per ton and a gold price of $\$ 500$ per ounce. The Donlin Creek 33.7-million-ounce gold re- source is one of the largest undeveloped gold resources in North America.

Liberty Star Gold Corp. conducted limited fieldwork on the 421-square-mile Big Chunk project. Liberty Star dropped about half of their Big Chunk claim block by the end of the year. Liberty Star staked 69 additional State of Alaska mining claims at the Bonanza Hills gold project about 40 miles northeast of the northern boundary of the Big Chunk claim block to cover strong gold and geochemical indicator metal stream sediment anomalies found during 2005 fieldwork. Fieldwork was planned at the Bonanza Hill property, but no results were released.

International Tower Hill Mines Ltd. made a joint-venture agreement with AngloGold to earn a 60 percent interest in the Terra project northeast of Lime Village. High-grade quartz veins, up to 8 ounces of gold per ton in rock samples, occur along a 5-mile structural zone with porphyryepithermal-style mineralization associated with the Terra Diorite. Tower Hill prospected the full strike length of the system and identified new high-grade gold veins. A twohole drilling program on the extension of the Ben Vein intersected high-grade intervals from these holes drilled on a 500-foot stepout. Hole TR-06-16 had five mineralized intercepts starting at 263-foot depth ranging from 1 foot to 7.2 feet wide with grades from 0.11 to 0.45 ounces of gold per ton. Hole TR-06-17 had two gold intercepts, with the thickest intercept from 422-foot to 436-foot depth and grading 0.65 ounces of gold per ton. Tower Hill collected 136 rock and rock chip channel samples, with values ranging up to 3.8 ounces of gold per ton and averaging 0.20 ounces of gold per ton and 0.98 ounces of silver per ton. Four main zones of veining are now defined in the core Terra target area, as well as a new zone of veining 2.5 miles to the south in the Ice Vein area (13 samples averaging 0.72 ounces of gold per ton and 4.96 ounces of silver per ton).

TNR Gold Corp. expanded known intrusion-related gold mineralization at the Shotgun property with a drilling program. TNR completed a total of 6,168 feet of diamond drilling in 11 holes on the Winchester and Shotgun zones with two drill rigs. The best geochemical results were in hole DDH06-45 at Winchester and averaged 0.055 ounces of gold per ton over 77 feet and hole DDH06-50 with 40 feet averaging 0.041 ounces of gold per ton. Gold-bearing igneous sills at the Winchester Zone cover a 1,500- by 1,100-foot area. Drillhole DDH06-43 at Shotgun Ridge averaged 0.038 ounces of gold per ton over 689 feet.

Tonogold Resources Inc., in a lease agreement with Calista Corp., continued gold exploration in the Nyac mining district. Mapping and geochemical sampling were done across the property, with 4,137 soil and 55 rock chip samples collected for analysis. High-grade quartz-chalcopyrite-pyrite veins were discovered at Saddle Mountain, 
with rock chip samples assaying up to 29 ounces of gold per ton. Tonogold drilled 11 core holes, totaling 8,383 feet, on Bonanza Ridge and the Wallace prospect, with partial results including a 2-foot intercept grading 0.25 ounces of gold per ton..

Full Metal optioned its Kamishak copper-gold project to Andover Ventures. A five-hole 2,925-foot core drilling program was completed. Drilling results confirmed the presence of porphyry style copper-gold mineralization, brecciation, and alteration. Drilling results include 241 feet starting at 93-foot depth averaging 0.31 percent copper and 0.008 ounces of gold per ton in hole KAS06-01, and 167 feet starting at 25 -foot depth averaging 0.48 percent copper and 0.013 ounces of gold per ton in hole KAS0604.

Pacific North West Capital Corp. signed an exploration and mining lease with Calista Corp. for the Goodnews Bay platinum property covering the Susie Mountain ultramafic complex. Pacific North West collected power auger soil samples, pan concentrate samples, and rock samples in addition to reconnaissance-scale prospecting. Anomalous platinum values up to $0.268 \mathrm{ppm}$ were found in soils overlying clinopyroxene-rich rocks on the southwest flank of Susie Mountain.

Brett Resources optioned the Sleitat Mountain tin property from Solomon Resources Ltd. Previous work had outlined significant tin mineralization as cassiterite in deeply eroded, steeply dipping greisen bodies adjacent to Tertiary granite. A five core hole drilling program totaling 2,305 feet was completed. Significant results include 341 feet, starting at 10 -foot depth, grading 0.24 percent tin and 0.19 ounces of silver per ton in hole Cass 06-10, and 206.5 feet, starting at 104.5 -foot depth, grading 0.29 percent tin and 0.41 ounces of silver per ton in hole Cass 06-11.

TNR Gold Corp. and Geocom Resources Inc. continued exploration at the $\mathrm{D}$ and $\mathrm{H}$ claims on the Iliamna project. Geocom planned a two core hole drilling program on the D claims. No results were announced.

Full Metal Minerals entered into an agreement with Moore Creek Mining Ltd. to acquire a 100 percent interest in the Moore Creek gold property. Placer gold is coarse-grained and angular at Moore Creek and a monzonitic pluton is present in the headwaters of gold-bearing creeks. Minor placer gold exploration was conducted on properties across the region.

\section{Alaska Peninsula Region}

Full Metal Minerals Ltd. and Metallica Resources Inc. continued exploration on Aleutian Islands and Alaska Peninsula properties controlled by Full Metal. Metallica completed two core holes at the Bee Creek prospect. Hole BC06-08 intersected 111.6 feet of 0.26 percent copper and 0.0025 ounces of gold per ton. Hole BC06-09 intersected 131.2 feet grading 0.51 percent copper and 0.006 ounces of gold per ton. Full Metal and Metallica also completed mapping, sampling, and ground geophysical surveys on the Kawisgag and Pyramid porphyry prospects.

Andover Ventures Inc. entered into an exploration agreement with Bristol Bay Native Corp. on the KUY, Fog Lake, Kemuk, Chilikat, and Samuelsen properties. Twelve rock samples collected on the KUY property from a 6- to 12-inch-wide quartz vein cutting Tertiary volcanic rocks had grades ranging from 0.19 to 27.4 ounces of gold per ton. Two 1.5-mile-long induced polarization (IP) geophysical lines were also completed on the property. One line draped the gold-bearing quartz vein and the second IP line was 1,000 feet to the south.

\section{Southeastern Region}

Niblack Mining Corp. explored the copper-gold-rich Niblack massive sulfide property on Prince of Wales Island. The exploration program included 27,000 feet of diamond drilling in 32 drill holes, environmental baseline studies, and construction of a 5,000-foot access road from tidewater to the future portal site. The portal site was cleared and readied to provide drilling access to potential deep mineralization below historic working. The drill program focused on the Lookout Zone, the most advanced area of the five known zones of massive sulfide mineralization on the property. A new exploration model includes multiple stacked massive sulfide lenses with predictable geometries and plunge directions and showed excellent potential for expanding known zones, as well as discovering new sulfide lenses. The longest mineralized interval drilled to date was intersected in hole LO-159, which includes three distinct massive sulfide lenses separated by stringer and disseminated sulfide mineralization grading 0.07 ounces of gold per ton, 1.37 ounces of silver per ton, 1.67 percent copper, and 4.05 percent zinc over 225.3 feet. Other significant mineralized drill intercepts include 27.2 feet grading 0.48 ounces of gold per ton, 4.41 ounces of silver per ton, 1.07 percent copper, and 16.26 percent zinc in hole LO-168; 16.3 feet grading 0.29 ounces of gold per ton, 4.06 ounces of silver per ton, 4.87 percent copper, and 15.42 percent zinc in hole LO-189; and 22.2 feet grading 1.15 ounces of gold per ton and 8.27 ounces of silver per ton of oxide mineralization in hole LO-176. Individual samples of massive sulfide contain up to 112.5 ppm gallium and 55.3 ppm indium and average 18 ppm selenium.

At the Greens Creek underground volcanogenic massive sulfide mine near Juneau, Kennecott Minerals Co. continued drilling south and west of current workings and development drifting to explore the West Gallagher Zone and additional reserves south of the 200 South, the West Bench, and the Deep Lower Southwest ore zones. The bulk of the underground exploration focused on the 5250 and West Gallagher zones, and an extension was discovered to the silver-rich 5250 zone. Kennecott drilled almost 60,000 
feet of core in underground exploration and more than 16,000 feet of core in surface exploration. Underground drifting for exploration totaled 683 feet.

Coeur Alaska Inc. continued gold exploration on its Kensington property near Juneau with an underground drilling program, while mine development continued.

Full Metal optioned the Mount Andrew copper-gold project on Prince of Wales Island from the Mount Andrew Mining Co. Full Metal completed a 1,580-foot core drilling program to test an iron oxide copper-gold mineralization model. Four of five holes encountered multiple intersections of magnetite-chalcopyrite mineralization. The best intercept was in hole KMA0601, with 98 feet of mineralization starting at 5-foot depth and grading 0.87 percent copper, 0.0035 ounces of gold per ton, and 0.10 ounces of silver per ton.

Bravo Venture Group Inc. conducted reconnaissance surface exploration of the "Blue Quartz" auriferous veins in the southwestern portion of Woewodski Island. Hand trenching was completed at the Miami Beach, Hattie, and Krause's showings. Previous rock samples from these showings had contained up to 15.87 ounces of gold per ton with low silver and pathfinder element values. Soil sampling occurred at the Miami Beach and Matt's vein showings, and prospecting was completed on a dozen other quartz veined areas. Mechanical trenching was scheduled for the Matt's vein showing. Samples from the new Red Quartz showing traced the vein system for 1,000 feet along strike and contained up to 0.11 ounces of gold per ton and 2.67 ounces of silver per ton, with elevated arsenic and antimony values.

Constantine Metal Resources Ltd., acquired the Palmer massive sulfide property from Toquima Mineral Corp. and drilled 2,720 feet of core in three holes at the RW zone. Hole CMR06-01 intersected 16.8 feet of massive sulfide grading 10.86 percent zinc, 0.13 percent lead, 0.23 percent copper, 0.004 ounces of gold per ton and 1.30 ounces of silver per ton. Hole CMR06-02 intersected a 2.59-foot wide massive sulfide lens grading 19.5 percent zinc. Several placer gold operations conducted trenching and bulk sampling.

\section{DEVELOPMENT}

Reported and estimated mineral development expenditures in 2006 were approximately \$331 million, a 5 percent decrease from the 2005 value of $\$ 347.9$ million. The decrease is primarily due to near-completion of the Pogo project construction during the year mostly offset by increased construction at the Kensington and Rock Creek projects. Other significant investments took place at the Fort Knox mine, at the Nixon Fork Mine, Chuitna Coal project and at Greens Creek Mine.

The Pogo mine, operated by Teck Pogo Inc., was commissioned during the year, officially on June 5, but capitalized expenditures continued and will extend into 2007 to bring the operation up to intended mining and treatment rates. Teck-Pogo, a subsidiary of Teck Cominco Inc., is the project operator and owns a 40 percent interest in the Pogo deposit. Co-owners are Sumitomo Metal Mining Co., owning a 51 percent interest, and Sumitomo Corp., owning 9 percent interest in the mine. Construction of the Pogo mine was completed in the first quarter except for the installation of the underground ore conveying system, which was fully commissioned in the second quarter. Inadequate tailings filtration capacity became apparent early in the mill commissioning process, thereby restricting mill throughput to 50-60 percent of design capacity. A major electrical power upset was experienced on October 19, when a contractor dug into a buried power cable. Temporary power was installed, allowing maintenance activities and construction projects to resume on October 22, and underground mining resumed on October 28. Mill operations resumed on December 14, after line power was restored. Despite the electrical incident, Pogo gold mine continued to make progress toward achieving full production capacity. A third pressure filter to improve filtration capacity was commissioned in January 2007. Construction is underway on modifications to the filtered tailings handling system to help paste backfilling, and is scheduled to be completed by March 2007. Gold production for 2007 is expected to be 340,000 ounces.

Construction at Coeur Alaska Inc.'s Kensington underground gold mine complex in southeastern Alaska, 45 miles north of Juneau, continued through 2006 although work on the tailings facility remained suspended. Efforts included construction of the mill and supporting surface facilities and underground development. Expenditures in 2006 totaled \$121.6 million. Employment, including contractors, numbered 385 persons during the year. At year-end, Coeur had 91 full-time employees on its payroll. The company currently estimates the actual cost of construction to be approximately \$238 million compared with the previous estimate of \$190 million; they plan to spend \$77.7 million on the project during 2007. Ore definition efforts during 2006 expanded reserves to 4,419,000 tons with a grade of 0.31 ounces of gold per ton containing 1,352,140 ounces of gold. Metallurgical recovery is expected to be 95.3 percent. Coeur plans a production rate of 100,000 ounces per year at a cash cost of $\$ 310$ per ounce. The milling process will involve treating approximately 1,100 tons of ore per day and will involve primary crushing, SAG mill grinding, gravity, and flotation concentration with about 40 percent of the tailings returned to the mine for backfill; the remaining tailings will be sent to the Lower Slate Lake tailings storage facility. Concentrates will be packaged and shipped off site for final gold recovery. The mine will provide about 225 direct and approximately 500 indirect jobs. Commercial production could begin in late 2007, subject to 
successful resolution of the permitting and litigation issues described below.

Construction was started in mid-2005 upon receipt of all permits, but on September 12, 2005, lawsuits were filed by private entities against the U.S. Army Corps of Engineers (COE) and the U.S. Forest Service (USFS), resulting in suspension on November 22, 2005, of construction of facilities to dispose of tailings in Lower Slate Lake. On March 29, 2006, the COE reinstated Coeur's Section 404 permit; however, on April 6, the lawsuit challenging the permit was re-opened. On August 4, 2006, the Federal District Court in Alaska dismissed the plaintiffs' challenge and upheld the permit. On August 7, 2006, the plaintiffs filed a Notice of Appeal of the decision to the Ninth Circuit Court of Appeals and on August 9, the plaintiffs additionally filed a Motion for Injunction Pending Appeal with the Circuit Court. The Circuit Court granted a temporary injunction pending appeal on August 24, enjoining certain activities relating to the lake tailings facility. The Circuit Court further ordered an expedited briefing schedule on the merits of the legal challenge. The parties filed their briefs by October 13, 2006, and participated in an oral argument on December 4, 2006. The U.S. Ninth Circuit Court of Appeals announced a ruling on March 16, 2007 that reversed the lower federal court decision and vacated the permits associated with the tailing facility. Coeur is awaiting the full explanation of this ruling and considering all appeal options.

NovaGold Resources Inc. received the necessary permits for its Rock Creek and Big Hurrah projects near Nome in August 2006 and a decision to commence construction was made; construction began in late August. Construction continued throughout the winter in upland areas and areas previously disturbed. Issuance of the air permit in December allowed the construction crew to start forming and pouring the foundation for facilities within the plant site and equipment service areas. Work at the plant site is proceeding on schedule and NovaGold continues to add experienced staff to the operations team. The Corps of Engineers suspended the Section 404 permit for the Rock Creek project on December 6, 2006, to review the permit evaluation and decision documents in response to a complaint that had been filed against the COE by a local Nome group arguing that there had not been a sufficient public process. On March 13, 2007, a modified permit was restored that contained additional stipulations covering reporting and mitigation; the company expects the permit restoration to be challenged. Certain critical equipment for the Rock Creek project was purchased in 2005 and delivered to the site in anticipation of the mine construction approval. Expenditures for mining and milling equipment and construction of facilities during 2006 were reported to be \$44.5 million. Measured and indicated resources at Rock Creek and Big Hurrah are 10.6 million tons at 0.0382 ounces of gold per ton and 1.98 million tons at 0.134 ounces of gold per ton, respectively.

Fairbanks Gold Mining Inc., a wholly owned subsidiary of Kinross Gold Corp., continued advanced stripping for accessing ore in phase VI of the Fort Knox Mine during 2006. In addition, Fairbanks Gold continued investigation and permitting of a valley-type heap leach for its lower grade materials. Total capital expenditures for this effort were \$49.9 million. Knight Piésold and Fairbanks Gold provided consulting services for the heap leach project. The heap is designed to contain 160 million tons of low-grade ore. The proposed pad will cover 279 acres. Proven and probable reserves at a gold price of \$475 per ounce were 176 million tons with a grade of 0.0154 ounces of gold per ton, containing 2.7 million ounces of gold. In addition, Measured and Indicated resources at a gold price of \$525 per ounce at Fort Knox on December 31, 2006, were 78.6 million tons containing 1.6 million ounces of gold ( 0.020 ounces per ton). Employment at the property at year-end was 369 persons; Fairbanks Gold intends to hire an additional 30 employees during 2007.

PacRim Coal LP continued permitting for the Chuitna Coal project, located west of Anchorage on the north side of Cook Inlet. PacRim released the Scoping Responsiveness Summary for the project's Supplemental Environmental Impact Statement. Previous work outlined 300 million tons of recoverable sub-bituminous coal with low sulfur content. The project is designed to include a coal export terminal connected to the mine with a 12-mile-long covered conveyor. Mine production capacity is designed to handle 3 to 12 million tons per year. Construction for this project is scheduled for 2007 with production in 2009. Construction costs will be approximately $\$ 650$ million.

Mystery Creek Resources, Inc., a wholly owned subsidiary of St. Andrew Goldfields Ltd., continued development at the Nixon Fork underground high-grade gold mine during the year. Underground access and stope construction were undertaken and some ore was stockpiled awaiting commissioning of the mill. The mill was upgraded to process 265 tons of ore per day from its previous capacity of 150 tons per day. The circuit will be completed in June with the addition of cyanidation capability. The current circuit includes crushing, grinding, gravity concentration, and flotation. A cyanide recovery circuit will be added beginning in June. Efforts in 2006 involved upgrading crushing and grinding equipment, removal of the old gravity circuit (spirals and tables), and installation of Falcon concentrator and screens. New cleaner tables were also installed. New power generation capability was added; three Cat 3508 generators (830 kW each) were installed. Carbon-in-leach circuitry will be added in 2007 to complete the upgrading process. A 350-ton-per-day Larox filter press will be added to produce dry stack capability for tailings. The operating cost is forecast to be $\$ 350$ per ounce. 
Mine life is expected to be 4 years. Employment will be 97 full-time jobs at commissioning.

The proven mineral reserve estimate is 51,800 tons with a grade of 0.99 ounces per ton containing 51,500 ounces of gold. An additional 151,570 tons of probable ore has been defined with a grade of 0.543 ounces per ton. The measured mineral resource estimate is 25,800 tons at an average grade of 1.07 ounces per ton containing 27,700 ounces of gold at a cutoff grade of 0.61 ounces per ton. An additional indicated resource of 138,900 tons with a grade of 0.63 ounces per ton has been calculated. An inferred resource of 102,500 tons with a grade of 0.452 ounces per ton has also been defined. Existing tailings amounting to 63,900 tons with a grade of 0.236 ounces per ton are included in the indicated and inferred resource.

Kennecott Greens Creek Mining Co. undertook underground development and surface facility improvement at the Greens Creek Mine. Greens Creek is owned by Kennecott Minerals Co. (70.27 percent) and Hecla Mining Co. (29.73 percent). Development activity was directed to driving 8,636 feet of primary and 1,435 feet of secondary access for the underground operations. Headings are 15 feet high by 15 feet wide. In addition, expenditures were undertaken to install infrastructure to augment the mine's diesel-generated power with less expensive hydroelectric power in the future, and an ongoing project to expand the tailings facility to be completed in two years. Contractors involved in this effort included Connors Drilling, Thyssen Mining, M3-Engineering, North Pacific Erectors, Channel Construction, and Larry Iverson Construction. Reserves at Greens Creek as of the end of 2006 were 7,677,000 tons at grades of 0.11 ounces of gold per ton, 14.4 ounces of silver per ton, 4.0 percent lead, and 10.4 percent zinc. Additionally, resources amounting to 2,414,000 tons with grades of 0.13 ounces of gold per ton, 13.8 ounces of silver per ton, 4.0 percent lead, and 10.4 percent zinc have been delineated at the mine.

\section{PRODUCTION}

A preliminary estimate of mineral production value in Alaska during 2006 is \$2,753 million. Reporting shortfalls are noted in the placer and industrial minerals sectors; when final totals are determined, the numbers are expected to increase. Metals (gold, silver, lead, and zinc) account for \$2,653 million, coal and peat for \$50 million, and industrial minerals for $\$ 50$ million. The estimate represents an increase in value of approximately $\$ 1,351$ million over the 2005 production value, even though production volumes are down in some sectors. Table 4 show the estimated mineral production for 2003 through 2006. Significant production sites are shown in figure 4.

The Red Dog Mine near Kotzebue in northwestern Alaska is the world's largest zinc producer and it dominated Alaska’s mineral production value. Red Dog accounted for well over 60 percent of the total value of Alaska's mineral industry during the year. The Red Dog Mine is 100 percent owned and operated by Teck Cominco Alaska Inc. under an agreement with NANA Regional Corp., a Native Alaskan development corporation. The Red Dog deposit comprises a number of sedimentary-hosted exhalative (SEDEX) lead-zinc sulfide deposits hosted in Mississippian- to Pennsylvanian-age sedimentary rocks. The ore bodies are lens shaped and occur within structurally controlled (thrust fault) plates. The sulfide mineralization consists of semi-massive to massive sphalerite, pyrite, marcasite, and galena. The mining method employed is conventional drill and blast open-pit mining. The main pit has an expected life of seven years at current rates of production. Additional reserves have been identified in the vicinity of the processing facilities sufficient to extend the life of the operation by 16 years for a total mine life of 23 years. The mineral processing facilities employ conventional grinding and sulfide flotation methods to produce zinc and lead concentrates. The shipping season at Red Dog is restricted to approximately 100 days per year because of sea ice conditions and Red Dog's sales are seasonal with the majority of sales in the last five months of each year. Concentrate is stockpiled at the port facility and is typically shipped between July and October.

Teck reported an operating profit at the Red Dog Mine of $\$ 1.1$ billion in 2006. The project milled 3.6 million tons of ore with a zinc grade of 20.63 percent and a lead grade of 6.08 percent. The project produced 614,538 tons of zinc, 136,135 tons of lead, and was credited with an estimated 2.4 million ounces of silver in 2006. Silver credits are calculated in the same manner as last year, but do not reflect the actual metal in concentrates. Efforts to define a useable gas source to replace diesel power generation continued during the year.

Greens Creek Mine, a Kennecott Minerals Co.-Hecla Mining Co. joint venture in southeastern Alaska, is a polymetallic volcanogenic massive sulfide deposit (silver, zinc, lead, gold, and copper) and one of the largest silver producers in the world. It produces a silver-gold doré and sulfide concentrates containing zinc, lead, and minor copper; copper is no longer reported.

Production at Greens Creek mine increased slightly from 2005 numbers. Mill throughput was 732,176 tons compared to a 2005 throughput of 717,600 tons. Metal production totaled 8,865,818 ounces of silver, 62,935 ounces of gold, 59,429 tons of zinc, and 20,992 tons of lead. Production numbers for 2005 were 9,700,000 ounces of silver, 72,800 ounces of gold, 58,350 tons of zinc, and 18,600 tons of lead. Manpower years were 295 persons for 2006.

Fairbanks Gold Mining Co., a wholly owned subsidiary of Kinross Gold, Inc., operated the open pit Fort Knox Mine near Fairbanks. Gold production increased 1.23 per- 
cent during 2006 compared to 2005, bringing total production for 2006 to 333,383 ounces. Mill throughput for 2006 was 14,839,297 tons compared to $14,384,842$ tons in 2005. Average recoverable grade was 0.0225 ounces per ton for 2006 compared to 0.0229 for 2005 . Waste stripping amounted to 35.0 million tons. Ore mining volume was 12.39 million tons and low grade; 3.68 million tons of low grade ore was delivered to the stockpile. Fort Knox celebrated a cumulative total of 3 million ounces of gold production in May.

Stripping of phase 6 was completed and mining of this phase was the only active segment in the pit at the end of the year. Phase 7 (southwest side), containing 33.1 million tons of mining production, is dependent on permitting of the Walter Creek Heap Leach facility. If and when permitted, stripping will commence on this phase during 2008. Phase 7 will allow the Fort Knox pit production to continue until 2015. Stockpile material will be mined and placed on the Walter Creek Heap Leach facility until 2017.

Usibelli Coal Mine Inc. continued production of subbituminous coal from its Two Bull Ridge site near Healy with an output of 1.4 million tons of coal, very slightly lower production than in 2005. Korean shipments contin- ued, with 352,367 tons to that destination via the Alaska Railroad to the Seward Coal terminal and by ship from that point. Shipments also continued to Chile in the amount of 80,673 tons for the year. The mine also supplies six power plants in interior Alaska with approximately 900,000 tons annually. Usibelli achieved an all-time safety record of no "lost time injuries" of 720 days extending from January 27,2004 , to January 16,2006 . After that date, the mine had no lost time injuries through the end of 2006 and that accomplishment continues to March 16, 2007.

Teck Pogo Inc., a subsidiary of Teck Cominco Inc., started mining and milling ore from the Pogo underground mine approximately 100 miles southeast of Fairbanks. The first ore throughput began in early 2006 and the first bar of gold was poured in mid February. Mill throughput was restricted due to a tailings filter limitation described under the Development section. The operation was further hindered by typical startup problems, as well as a major power failure in October. Mill throughput was approximately 250,000 tons for the year and gold production was 112,500 ounces. Employment has not been reported, but hiring of skilled underground miners has been very difficult and has hindered the ability of the underground mine to reach intended capacity.

Table 4. Estimated mineral production in Alaska, 2004-2006

\begin{tabular}{|c|c|c|c|c|c|c|}
\hline \multirow[b]{2}{*}{ Metals } & \multicolumn{3}{|c|}{ Quantity } & \multicolumn{3}{|c|}{ Estimated Values ${ }^{\mathbf{b}}$} \\
\hline & 2004 & 2005 & 2006 & 2004 & 2005 & 2006 \\
\hline Gold (ounces) ${ }^{\mathrm{C}}$ & 456,508 & 427,031 & 574,818 & $192,343,315$ & $189,918,000$ & $336,071,222$ \\
\hline Silver (ounces) & $16,947,270$ & $11,670,000$ & $8,865,818$ & $113,056,930$ & $85,382,000$ & $130,298,034$ \\
\hline Copper (tons) ${ }^{\mathrm{d}}$ & $0^{\mathrm{d}}$ & $0^{\mathrm{d}}$ & $0^{d}$ & 0 & 0 & 0 \\
\hline Lead (tons) & 150,796 & 131,366 & 157,128 & $120,636,822$ & $115,230,000$ & $183,629,254$ \\
\hline Zinc (tons) & 680,015 & 684,462 & 673,967 & $651,432,200$ & $862,108,000$ & $2,002,971,414$ \\
\hline Subtotal & & & & $\$ 1,077,469,267$ & $\$ 1,252,638,000$ & $\$ 2,652,969,924$ \\
\hline \multicolumn{7}{|l|}{ Industrial Minerals } \\
\hline Jade and soapstone (tons) & $0.0^{\mathrm{e}}$ & 0.0 & 0.0 & 0 & 0 & 0 \\
\hline Sand and gravel (million tons & 19.6 & 16.6 & 6.2 & $101,507,347$ & $76,537,000$ & $40,753,788$ \\
\hline Rock (million tons) & 7.3 & 2.8 & 0.9 & $106,207,814$ & $22,547,000$ & $9,125,744$ \\
\hline Subtotal & & & & $\$ 207,715,161$ & $\$ 99,084,000$ & $\$ 49,879,532$ \\
\hline Coal (tons) & $1,450,000$ & $1,402,174$ & $1,397,500$ & $50,750,000$ & $49,076,000$ & $48,912,500$ \\
\hline Peat (cubic yards) & 208,032 & 62,532 & 55,000 & 2,732,554 & 810,000 & 885,000 \\
\hline Subtotal & & & & $\$ 53,482,554$ & $\$ 49,886,000$ & $\$ 49,797,500$ \\
\hline TOTAL & & & & $\$ 1,339,257,667$ & $\$ 1,401,608,000$ & $\$ 2,752,646,956$ \\
\hline
\end{tabular}

aproduction data from DGGS questionnaire, phone interviews with mine and quarry operators, ADOT\&PF, and municipalities, Regional Corp., and federal land management agencies.

${ }^{\text {b}}$ Values for selected metal production was based on average prices for each year; (unless other values were provided by the operator); for 2006, gold \$603.46, silver \$11.35/oz, lead \$0.58/lb, zinc \$1.47/lb.

'Hardrock gold - 566,383 ounces, placer gold $-8,435$ ounces.

${ }^{\mathrm{d}}$ Greens Creek has historically been credited with a small copper concentrate production; no credit was experienced for 2003 - 2006.

eJade and soapstone credit has been dropped. 


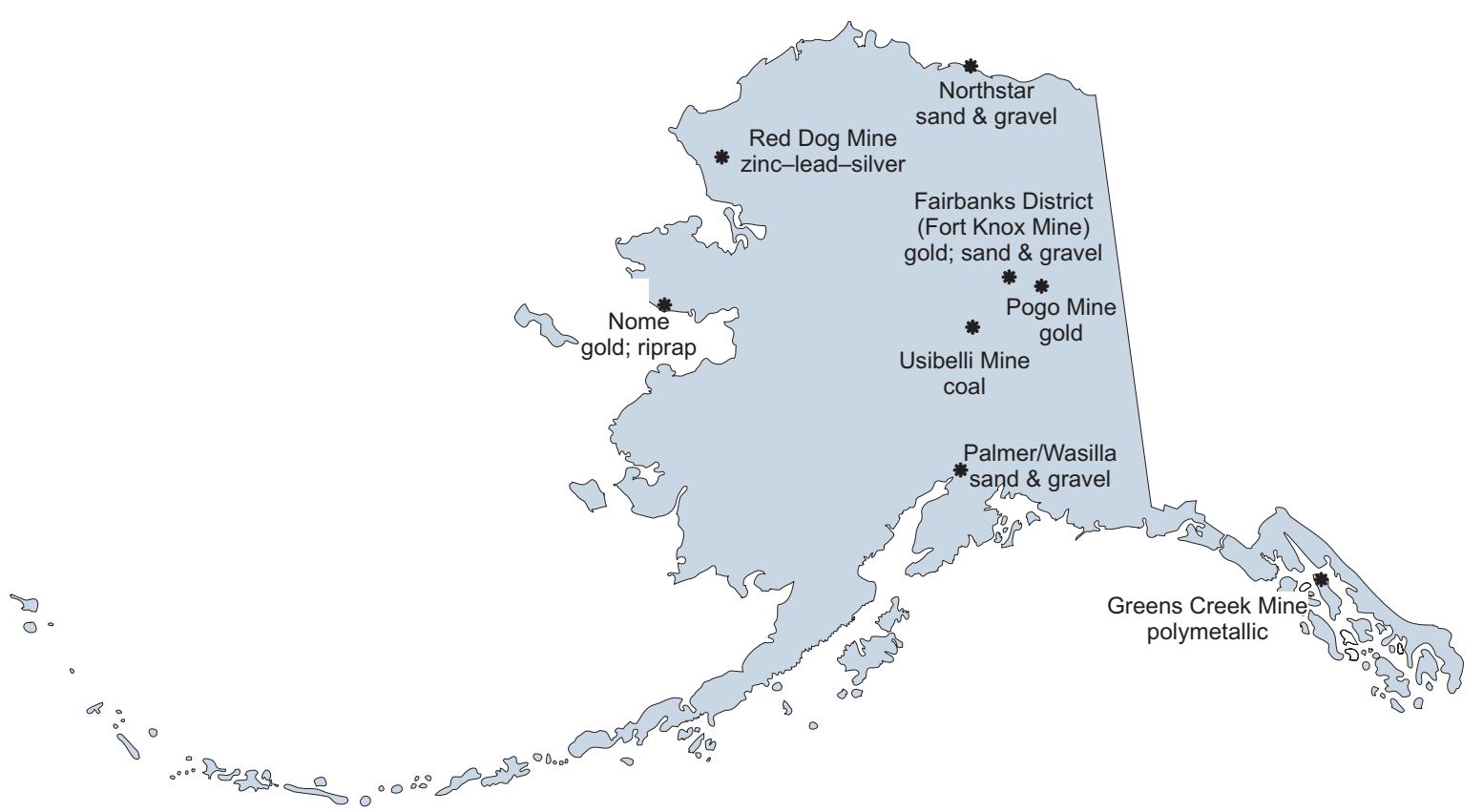

Figure 4. Selected significant production sites in Alaska, 2006.

Reported placer production to this date is notably incomplete, and is approximately 8,400 ounces; final production is expected to achieve 2005 levels of about 25,000 ounces with more information. The number of operations reporting to date is 24 . Silverado Gold Mines Ltd.'s underground placer operation on Nolan Creek in the Brooks Range milled about 6,100 cubic yards of ore that was mined in late 2005 and early 2006. A total of 939 ounces of gold was recovered including a 14-ounce nugget.

Recreational mining is becoming more prominent or at least becoming more recognized. Information on this sector of the industry will be reported in more detail in the final report released in November.

Production information for the non-metallic mining sector, rock, sand, and gravel is also incomplete at this time. As of the publishing date, the value of production is approximately $\$ 50$ million but is expected to rise to near last year's levels as additional production statistics compiled.

\section{DRILLING}

Tables 5 and 6 summarize the drilling activity in the state during 2006 by region and type of drilling. Drilling was conducted during all phases of mining (exploration, development, and production) on various projects across Alaska during the year. Preliminary drilling totals for 2006 are 727,513 feet of core drilling, 23,173 feet of reversecirculation drilling, and 8,656 feet of placer auger/churn drilling. There was no drilling reported for coal operations. The drilling results are considered incomplete at this time.
Major drilling programs were conducted in most areas of the state. Barrick Gold had the largest drill program in Alaska with more than 302,000 feet of core drilling on the Donlin Creek property. The largest programs were in southwestern Alaska, with drilling by Barrick Gold Inc. on the Donlin Creek property, Northern Dynasty Minerals Ltd. at the Pebble property, TNR Gold Corp. at the Shotgun property, and Tonogold Resources Inc. in the Nyac area. Drilling programs in southeastern Alaska were conducted by Kennecott Minerals Co. with surface and underground drilling at Greens Creek Mine, Coeur Alaska Inc. at the Kensington and Jualin properties, and by Niblack Mining Corp. on the Niblack property. A major drilling program was conducted in the eastern Interior region by Teck Pogo Inc. on the Pogo property in the Goodpaster mining district. Little Squaw Mining Co. conducted a large reverse-circulation drilling program on the Little Squaw property in the Chandalar area. Triex Minerals Corp. drilled the Boulder Creek uranium property on the Seward Peninsula. In southcentral Alaska, major drilling programs were conducted by Full Metal Minerals Ltd. at the Lucky Shot property, by Kennecott Exploration Co. at the Whistler property, and by Anglo American on the MAN property. International Tower Hill Mines Ltd. drilled at several properties including the LMS and Terra projects. NovaGold Resources Inc. drilled at the Rock Creek, Big Hurrah, Khotol, and Arctic properties in the northern and western regions. St. Andrew Goldfields Ltd./Mystery Creek Resources Inc. continued underground drilling at the Nixon Fork property. 
Table 5. Drilling footage by region in Alaska, 2006

\begin{tabular}{|c|c|c|c|c|c|c|c|c|}
\hline Type of drilling & Northern & Western & $\begin{array}{l}\text { Eastern } \\
\text { Interior }\end{array}$ & $\begin{array}{l}\text { South- } \\
\text { central }\end{array}$ & $\begin{array}{c}\text { South- } \\
\text { western }\end{array}$ & $\begin{array}{l}\text { South- } \\
\text { eastern }\end{array}$ & $\begin{array}{c}\text { Alaska } \\
\text { Peninsula }\end{array}$ & TOTAL \\
\hline Placer subtotal & 6,419 & 12 & 2,185 & 40 & -- & -- & -- & 8,656 \\
\hline Coal subtotal & - - & -- & -- & -- & -- & -- & -- & $\mathbf{0}$ \\
\hline Hardrock core & 9,876 & 21,718 & 78,277 & 61,975 & 399,368 & 154,196 & 2,103 & 727,513 \\
\hline Hardrock rotary & 8,063 & 0 & 12,610 & 2,500 & 0 & 0 & 0 & 23,173 \\
\hline Hardrock subtotal & 17,939 & 21,718 & 90,887 & 64,475 & 399,368 & 154,196 & $\mathbf{0}$ & 750,686 \\
\hline TOTAL (feet) & 24,358 & 21,730 & 93,072 & 64,515 & 399,368 & 154,196 & $\mathbf{0}$ & 759,342 \\
\hline
\end{tabular}

- - = Not reported.

Drilling footages do not include sand and gravel drilling.

Table 6. Drilling footage reported in Alaska, 1982-2006

\begin{tabular}{|c|c|c|c|c|c|c|c|c|}
\hline Year & $\begin{array}{c}\text { Placer } \\
\text { Exploration }\end{array}$ & $\begin{array}{l}\text { Placer } \\
\text { Thawing }\end{array}$ & $\begin{array}{l}\text { TOTAL } \\
\text { PLACER }\end{array}$ & $\begin{array}{l}\text { TOTAL } \\
\text { COAL }\end{array}$ & $\begin{array}{c}\text { TOTAL } \\
\text { HARDROCK }\end{array}$ & $\begin{array}{c}\text { Hardrock } \\
\text { Core }^{\mathrm{a}}\end{array}$ & $\begin{array}{l}\text { Hardrock } \\
\text { Rotary }^{\mathrm{a}}\end{array}$ & $\begin{array}{l}\text { TOTAL } \\
\text { FEET }\end{array}$ \\
\hline 1982 & 30,000 & 94,000 & 124,000 & 80,000 & 200,000 & - - & - - & 404,000 \\
\hline 1983 & 23,000 & 30,000 & 53,000 & 12,000 & 180,500 & -- & -- & 245,500 \\
\hline 1984 & 31,000 & 98,000 & 129,000 & 25,700 & 176,000 & -- & -- & 330,700 \\
\hline 1985 & 46,000 & 34,000 & 80,000 & 8,700 & 131,700 & -- & - & 220,400 \\
\hline 1986 & 32,400 & 227,000 & 259,400 & 28,800 & 50,200 & - - & - - & 338,400 \\
\hline 1987 & 50,250 & 130,000 & 180,250 & 19,900 & 115,100 & 95,600 & 19,500 & 315,250 \\
\hline 1988 & 152,000 & 300,000 & 452,000 & 26,150 & 353,860 & 223,630 & 130,230 & 832,010 \\
\hline 1989 & 97,250 & 210,000 & 307,250 & 38,670 & 332,230 & 242,440 & 89,790 & 678,150 \\
\hline 1990 & 78,930 & 105,000 & 183,930 & 18,195 & 760,955 & 648,600 & 112,355 & 963,080 \\
\hline 1991 & 51,247 & 130,000 & 181,247 & 16,894 & 316,655 & 205,805 & 110,850 & 514,796 \\
\hline 1992 & 6,740 & 65,000 & 71,740 & 12,875 & 359,834 & 211,812 & 148,022 & 444,449 \\
\hline 1993 & 25,216 & - - & 25,216 & - - & 252,315 & 124,325 & 127,990 & 277,531 \\
\hline 1994 & 21,000 & -- & 21,000 & 8,168 & 438,710 & 347,018 & 91,692 & 467,878 \\
\hline 1995 & 27,570 & -- & 27,570 & - - & 415,485 & 363,690 & 51,795 & 443,055 \\
\hline 1996 & 61,780 & -- & 61,780 & 8,500 & 658,857 & 524,330 & 134,527 & 729,137 \\
\hline 1997 & 38,980 & -- & 38,980 & 13,998 & 704,510 & 523,676 & 180,834 & 757,488 \\
\hline 1998 & 33,250 & -- & 33,250 & 2,300 & 551,078 & 505,408 & 45,670 & 586,628 \\
\hline 1999 & 6,727 & -- & 6,727 & - - & 448,797 & 369,863 & 78,934 & 455,524 \\
\hline 2000 & 15,480 & -- & 15,480 & - - & 546,268 & 418,630 & 127,638 & 561,748 \\
\hline 2001 & 1,100 & - & 1,100 & 36,151 & 316,068 & 240,318 & 75,750 & 353,319 \\
\hline 2002 & 1,250 & -- & 1,250 & - - & 488,902 & 385,290 & 103,612 & 490,152 \\
\hline 2003 & 10,108 & -- & 10,108 & 2,000 & 370,634 & 270,456 & 100,178 & 382,742 \\
\hline 2004 & 107,526 & -- & 107,526 & - - & 451,652 & 415,628 & 36,024 & 559,178 \\
\hline 2005 & 3,360 & - - & 3,360 & -- & 634,277 & 592,497 & 41,780 & 637,637 \\
\hline 2006 & 8,656 & -- & 8,656 & -- & 750,686 & 727,513 & 23,173 & 759,342 \\
\hline
\end{tabular}




\section{GOVERNMENT ACTIONS}

Geologists from the Minerals Resources Section of the Alaska Division of Geological \& Geophysical Surveys (DGGS) mapped and sampled 308 square miles of the Casadepaga River, Bear River, and Bluff areas of the southern Seward Peninsula. A 1:50,000-scale geologic map will be available in late 2007. This fieldwork is part of an integrated program following the airborne geophysical survey results previously released by DGGS in 2003 and previous fieldwork conducted in 2004 in the Council and Big Hurrah areas.

The State of Alaska, through DGGS, funded and acquired airborne magnetic and electromagnetic geophysical surveys for 600 square miles in a highly prospective area for base-metal and gold deposits in the Bonnifield mining district. DGGS in late January 2006 released the geophysical data and maps for four areas, Northeast Fairbanks, East Richardson, Liscum, and Black Mountain of Interior Alaska. The surveys were conducted by Fugro Airborne Surveys Corp. and managed by Stevens Exploration Management Corp. These data, all historic DGGS publications, and most U.S. Geological Survey publications on Alaska are available for free download at the DGGS Web site (http://www.dggs.dnr.state.ak.us).

To date, with an investment of $\$ 6.6$ million, in excess of 6.5 million acres (more than 10,100 square miles) of Alaska were flown for detailed geophysical surveys and about 2.7 million acres of 1:63,360-scale geologic maps were produced as part of the State-funded Alaska Airborne Geophysical/Geological Mineral Inventory (AGGMI) Program. Federal monies from the U.S. Geological Survey's STATEMAP Program fund some of the geologic mapping within the AGGMI Program.

DGGS released airborne geophysical survey data for a 3,045-square-mile area along the Alaska Highway from Delta Junction to the Canadian border that may include future development such as a natural gas pipeline, a railroad extension, or other infrastructure. The digital and paper copy release includes total field aeromagnetic and electromagnetic data. The electromagnetic data were acquired with a configuration designed to maximize information about near-surface materials such as sand and gravel resources, conductive overburden, and the location of potential geologic hazards such as permafrost and faults. The new data will be used to provide basic engineering, geologic, and resource planning information for future development in the area.

The DGGS Geologic Materials Center (GMC) received samples and data during the year, including geologic logs and assays from drill holes completed in 1981 and 1982 at the Coal Creek tin property in the Talkeetna Mountains Quadrangle.

DGGS requested input from the Alaska mineral industry for the formation of a voluntary sponsor group to help financially support DGGS's mineral-resource programs. This program would be modeled after the successful energy industry sponsorship program for DGGS's energy-related field studies and supporting analyses. Participating individuals and companies would be given the opportunity to meet with DGGS personnel in the field during the work to learn of the findings. Public input concerning the scope and nature of the program is encouraged.

Governor Sarah Palin appointed Marty Rutherford as the Department of Natural Resources' Acting Commissioner in November to replace the former administration's Commissioner Mike Menge. Governor Palin later appointed Tom Irwin as DNR Commissioner and Marty became the Deputy Commissioner in charge of gas pipeline negotiations.

The federal coastal oversight agency, National Oceanic \& Atmospheric Administration's Ocean \& Coastal Resource Management (NOAA/OCRM) gave final approval to the state's revised coastal management plan on December 29, 2005. Management plans for 9 of the 28 coastal districts were approved by NOAA/OCRM by the end of 2006. Six more coastal district plans were approved by February 7, 2007, with a timetable to approve all plans by September 1, 2007, which is the new date that existing plans will sunset.

On June 29, 2006, the State of Alaska formally applied to the U.S. Environmental Protection Agency (EPA) for authority to permit wastewater discharges in Alaska. Currently, EPA issues National Pollutant Discharge Elimination System (NPDES) permits, which are then certified by the Alaska Department of Environmental Conservation (DEC). The Clean Water Act establishes the NPDES wastewater permit program and encourages states to implement the program. The EPA provided an extensive list of comments on DEC's application on October 31 2006, and met with DEC staff in mid November 2006 to discuss and clarify those comments. The EPA believes that there are several statutory shortcomings that must be corrected in order to demonstrate that DEC has the necessary authority to implement the NPDES program. DEC and EPA developed a work plan and process to address all EPA comments and to make necessary revisions to the NPDES application components. DEC plans to resubmit the NPDES application to EPA by June 15, 2007.

A geophysical survey funded by the U.S. Bureau of Land Management for 1,450 square miles of mineral-rich lands in the southern National Petroleum Reserve-Alaska (NPR-A) were flown in 2005 and released by DGGS in early 2006. The survey includes portions of the Howard Pass and Misheguk Mountain quadrangles and was carried out to assist the BLM in a resource assessment of the southern NPR-A. The southern NPR-A contains 22 documented mineral occurrences including the Drenchwater 
Creek sedex-type deposit, bedded barite occurrences, and bedded phosphate occurrences. The survey was conducted by Fugro Airborne Surveys Corp. and managed by Stevens Exploration Management Corp.

The BLM and DGGS are preparing to conduct an aeromagnetic survey for a large part of the Goodnews Bay and part of the Hagemeister Island quadrangles in southwestern Alaska. The survey is funded by BLM through a cooperative agree-ment with DGGS in support of DGGS's statewide airborne geophysical survey program. The Goodnews Bay area hosts historic production of placer platinum and platinum-group elements (PGE) that at one time represented the only PGE production in the United States.

The U.S. Geological Survey (USGS) contracted for an aeromagnetic survey of the Dillingham Quadrangle and released the data in mid 2006. The USGS continued fieldwork in the Taylor Mountains Quadrangle of southwestern Alaska, with geologic mapping conducted in the southeastern corner of the quadrangle and stream-sediment sampling concentrated in the western quarter of the quadrangle.

The national U.S. Bureau of Land Management (BLM) 2006 Hardrock Mineral Community Outreach and Economic Security Award was won by Coeur Alaska's Kensington Project. Mike and Lou Busby, doing business as GeoQuest and Chicken Gold won the Small Operator Award. State reclamation awards for 2006 were awarded to Usibelli Coal Mine, Golderado Mining Co., Nyac Mining Co., and EarthMovers of Fairbanks Inc. by the Alaska Department of Natural Resources (DNR).

Dirk Kempthorne, Secretary of the U.S. Department of the Interior, announced the appointment of five members to the Alaska BLM Resource Advisory Council (RAC): Denise Michels, mayor of Nome, was appointed as a new member; reappointed members include Philip Driver, Midnight Sun Adventures; Suzanne McCarthy, Prince William Sound Community College; Teresa Imm, Arctic Slope Regional Corp.; and Keith Tryck, Tryck Consulting.

Mark Myers, former Director of DNR's Division of Oil \& Gas, was confirmed as the Director of the U.S. Geological Survey in September 2006. The U.S. Geological Survey has 10,000 scientists, technicians, and support staff in nearly 400 offices in every state and several foreign countries.
The National Energy Technology Laboratory (NETL) released Phase 1 of the Beluga Coal Gasification report dealing with use of coal-based integrated gasification combined cycle (IGCC) plant to produce a feedstock for the Agrium fertilizer plant at Nikiski. Phase 2 of the study will assess a Fischer/Tropsch coal-to-liquids (CTL) plant at Usibelli Coal Mine's Emma Creek site that would utilize 4 million tons per year of coal to produce about 13,000 barrels per day of product.

The Alaska Energy Authority (AEA) dedicated a new geothermal power plant at Chena Hot Springs Resort on August 20, 2006. The Chena Hot Springs geothermal power plant is the only geothermal power plant built in the United States during 2006 and boasts the world's lowest temperature geothermal resource ever trapped for power generation. Geothermal water at Chena Hot Springs never reaches its boiling point, so a traditional steam-driven turbine cannot be used. Instead, a secondary ("binary”) fluid, R-134a, which has a lower boiling point than water, passes through a heat exchanger with $165^{\circ} \mathrm{F}$ water from the geothermal wells. Heat from the geothermal water causes the R-134a fluid to flash to vapor, which then drives the turbine. The Chena Power Plant generates power economically off a $120^{\circ} \mathrm{F}$ temperature differential between the evaporator and condenser temperature. All buildings at the resort are linked by a geothermal district-heating system and the geothermal power plant will alleviate the need for approximately 162,000 gallons of diesel fuel previously used for power. The cost of power production is expected to be reduced from \$0.30 to less than $\$ 0.07$ per kilowatt hour at Chena Hot Springs Resort by utilizing geothermal power.

AIDEA was negotiating with Sherwood Copper Corp. for the use of the Skagway Ore Terminal to handle shipments of Sherwood's production from a proposed copper-gold mine near Minto in the Yukon Territory.

Anchorage Sand \& Gravel Co. Inc. (AS\&G) was awarded the 15th annual Made In Alaska Manufacturer of the Year Award. AS\&G is one of the oldest companies in Alaska, getting their start along the banks of Ship Creek in Anchorage in 1938. 


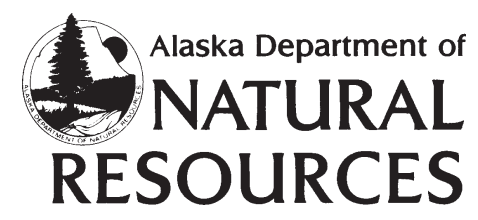

\section{DEPARTMENT OF NATURAL RESOURCES \\ Division of Geological \& Geophysical Surveys http://www.dggs.dnr.state.ak.us}

\section{DEPARTMENT OF COMMERCE, COMMUNITY \& ECONOMIC DEVELOPMENT}

Office of Economic Development

http://www.commerce.state.ak.us/oed/minerals/mining.htm

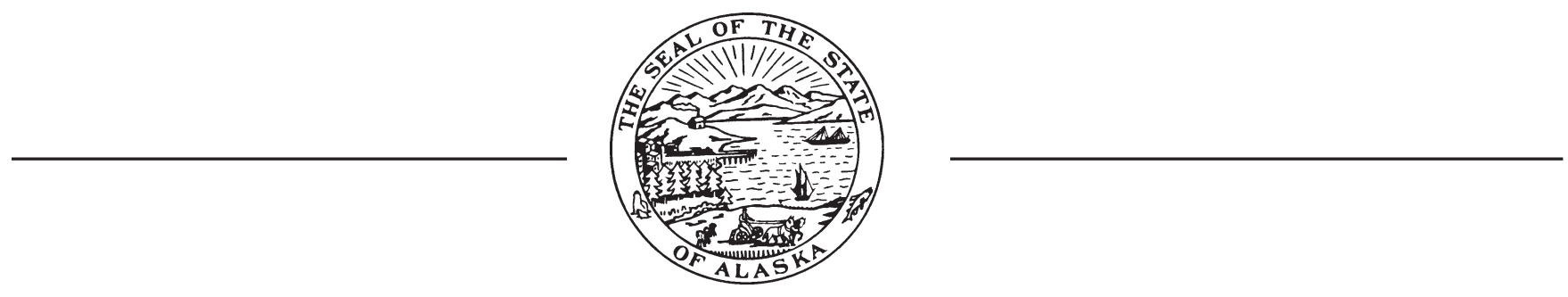

